\title{
Article \\ Origin of Platinum Group Minerals (PGM) Inclusions in Chromite Deposits of the Urals
}

\author{
Federica Zaccarini ${ }^{1, *}$, Giorgio Garuti ${ }^{1}$, Evgeny Pushkarev ${ }^{2}$ and Oskar Thalhammer ${ }^{1}$ \\ 1 Department of Applied Geosciences and Geophysics, University of Leoben, Peter Tunner Str.5, \\ A 8700 Leoben, Austria; giorgio.garuti1945@gmail.com (G.G.); oskar.thalhammer@unileoben.ac.at (O.T.) \\ 2 Institute of Geology and Geochemistry, Ural Branch of the Russian Academy of Science, Str. Pochtovy per. 7, \\ 620151 Ekaterinburg, Russia; pushkarev@igg.uran.ru \\ * Correspondence: federica.zaccarini@unileoben.ac.at; Tel.: +43-3842-402-6218
}

Received: 13 August 2018; Accepted: 28 August 2018; Published: 31 August 2018

\begin{abstract}
This paper reviews a database of about 1500 published and 1000 unpublished microprobe analyses of platinum-group minerals (PGM) from chromite deposits associated with ophiolites and Alaskan-type complexes of the Urals. Composition, texture, and paragenesis of unaltered PGM enclosed in fresh chromitite of the ophiolites indicate that the PGM formed by a sequence of crystallization events before, during, and probably after primary chromite precipitation. The most important controlling factors are sulfur fugacity and temperature. Laurite and Os-Ir-Ru alloys are pristine liquidus phases crystallized at high temperature and low sulfur fugacity: they were trapped in the chromite as solid particles. Oxygen thermobarometry supports that several chromitites underwent compositional equilibration down to $700{ }^{\circ} \mathrm{C}$ involving increase of the $\mathrm{Fe} 3 / \mathrm{Fe} 2$ ratio. These chromitites contain a great number of PGM including — besides laurite and alloys-erlichmanite, Ir-Ni-sulfides, and Ir-Ru sulfarsenides formed by increasing sulfur fugacity. Correlation with chromite composition suggests that the latest stage of PGM crystallization might have occurred in the subsolidus. If platinum-group elements (PGE) were still present in solid chromite as dispersed atomic clusters, they could easily convert into discrete PGM inclusions splitting off the chromite during its re-crystallization under slow cooling-rate. The presence of primary PGM inclusions in fresh chromitite of the Alaskan-type complexes is restricted to ore bodies crystallized in equilibrium with the host dunite. The predominance of Pt-Fe alloys over sulfides is a strong indication for low sulfur fugacity, thereby early crystallization of laurite is observed only in one deposit. In most cases, Pt-Fe alloys crystallized and were trapped in chromite between 1300 and $1050{ }^{\circ} \mathrm{C}$. On-cooling equilibration to $\sim 900{ }^{\circ} \mathrm{C}$ may produce lamellar unmixing of different $\mathrm{Pt}-\mathrm{Fe}$ phases and osmium. Precipitation of the Pt-Fe alloys locally is followed by an increase of sulfur fugacity leading to crystallize erlichmanite and Ir-Rh-Ni-Cu sulfides, occurring as epitaxic overgrowth on the alloy. There is evidence that the system moved quickly into the stabilization field of Pt-Fe alloys by an increase of the oxygen fugacity marked by an increase of the magnetite component in the chromite. In summary, the data support that most of the primary PGM inclusions in the chromitites of the Urals formed in situ, as part of the chromite precipitation event. However, in certain ophiolitic chromitites undergoing annealing conditions, there is evidence for subsolidus crystallization of discrete PGM from PGE atomic-clusters occurring in the chromite. This mechanism of formation does not require a true solid solution of PGE in the chromite structure.
\end{abstract}

Keywords: chromitite; platinum group minerals; primary inclusions; ophiolite; Alaskan-type complex.; Urals; Russia 


\section{Introduction}

Ever since pioneer geochemical surveys of ultramafic rocks [1-13], chromitite has been recognized as a potential concentrator of platinum-group elements (PGE $=\mathrm{Os}, \mathrm{Ir}, \mathrm{Ru}, \mathrm{Rh}, \mathrm{Pt}, \mathrm{Pd}$ ). These metals are mainly carried in minute grains $(<20 \mu \mathrm{m})$ of specific platinum-group minerals (PGM) that occur enclosed in chromite crystals, at the crystal rims or in the interstitial silicate gangue of the chromitite. Because of their textural position the PGM not included in chromite are exposed to alteration and can be remobilized at a small scale by the action of low-temperatures hydrous fluids $[8,12]$. The PGM included in fresh chromite are preserved by alteration and generally are considered to have crystallized at high temperature. Since the beginning, it was established that some chromitites preferentially concentrate IPGE (Os, Ir, Ru), and others are dominated by PPGE ( $\mathrm{Rh}, \mathrm{Pt}, \mathrm{Pd})$, depending on PGE fractionation during crystallization of the parent melt, and partial melting of the mantle source. Apart from this question, there has been considerable debate concerning the mechanism by which discrete PGM crystals are enclosed in the chromite. Some authors have interpreted the PGM to have exsolved from the oxide host at some subsolidus stage, and actually experimental works have demonstrated that some PGE have crystal-chemical compatibility for the spinel structure, being incorporated as a true solid solution in the oxide [9]. However, some factual observations strongly argue against this model as the sole mechanism for the formation of PGM in chromitite. For example, dissolution-exsolution cannot explain the mineralogical diversity of PGM included in a single chromite crystal, neither can it account for the compositional similarity of PGM found included in chromite and co-crystallizing mafic silicates $[4-6,10]$. There is now a general consensus that the primary PGM are pristine liquidus phases mechanically trapped in chromite and mafic silicates precipitating from the magma at high temperature would appear the most likely. This model may easily account for the mineralogical variability of PGM-bearing composite inclusions reported from a number of chromitites, and does not require crystallographic substitution of PGE in the framework of chromite and mafic silicates [6,11-13]. The crystallization of PGM at high temperature is somehow supported by the so called "clusters theory" [14]. These authors suggested that in natural magmas the PGE do not occur as free cations or any other molecular species, but form disordered clusters consisting of a few hundred atoms, suspended in the melt. Because of their physical and chemical properties the clusters will tend to coalesce with decreasing temperature to form specific PGM alloys, sulfides, or compounds with other ligands (e.g., As, Te, Bi, Sb). The "clusters theory" has received much attention from the students since it can explain many characters of the primary PGM inclusions in chromitites. Nevertheless, the magmatic association between chromite and PGE at high temperature still presents some unresolved questions which need further investigation [15].

The chromite deposits of the Urals offer a unique opportunity to study genetic mechanisms of the chromite-PGE mineralization associated with ophiolites and Alaskan-type ultramafic complexes. These chromitites formed by a sequence of magmatic events marking the geodynamic evolution of the Uralian Ocean, from its opening in Ordovician pre-Palaeozoic to closure in Upper Devonian-Carboniferous Permo-Triassic times.

Preliminary overviews have revealed that chromitites associated with ophiolites and Alaskan-type intrusions have distinct Os-Ir-Ru or Ir-Rh-Pt-Pd geochemical specialization, respectively $[7,16]$, providing a useful guideline for the interpretation of the primary source of PGE nuggets in alluvial placer deposits of the Urals [7,16,17]. Mineralogical investigations carried out between 1996 and 2016 have described in detail the diverse PGM assemblages of the chromitites, thereby establishing a close consistency between the geochemistry and mineralogy of the PGE [18-45]. The results of these studies, however, did not lead to a conclusive model able to adequately explain the primary origin of PGM inclusions in the chromite. Several aspects remain unsolved, for example, the physical state of the PGM at the time of entrapment (liquid, solid crystals, solid + liquid), or the effects of chromite re-equilibration in the subsolidus. The introduction of the "cluster theory" [14] clearly provides further argument for debate making the role of the re-adjustment of PGM assemblages in the subsolidus stage more likely. In order to contribute to the discussion, we have examined approximately 2500 
microprobe analyses of PGM grains, partly taken from the above literature and partly provided by new analyses carried out in the course of this overview. A survey of electron-microscope images of primary PGM inclusions in the fresh chromite is provided, in order to illustrate crystallization relations among the different PGM phases. Comparison of PGE-PGM data with chromite composition allows us to explore the possible correlation between the type of PGM mineralization and conditions invoked for the precipitation of chromite at high magmatic temperature, or the influence of chromite on-cooling equilibration in the subsolidus stage.

\section{Geological Setting and Sample Provenance}

Ural orogenic belt extends over $2500 \mathrm{~km}$ along the $60^{\circ}$ East Meridian (Figure 1A). Ophiolites and Alaskan-type complexes hosting the chromite deposits examined in this overview occur distributed along the axial zone of the Ural belt (Figure 1B). Geologic classification of the chromite deposits [46] includes: (1) Mantle-hosted ophiolitic chromitite (Ray-Iz, Alapaevsk, Kluchevsk, Nurali, Kraka, Kempirsai Main Ore Field); (2) Banded chromitite in supra-Moho cumulate of ophiolites (Nurali, Kempirsai Batamshinsk, Tagashasai, Stepninsk); (3) Chromitite lenses in Alaskan-type zoned intrusions (Kytlym, Kachkanar, Nizhny Tagil, Uktus) (Table 1). Type-1 chromitites are characterized by high-Cr, low-Ti composition and are hosted in harzburgite or lherzolite type ophiolites; most deposits have economic size. Type- 2 chromitites have high-Al composition, but their Ti content varies from low to high according to the type of host-rock, dunite, pyroxenite, troctolite, clinopyroxenite. Type-3 chromitites have high-Cr, high-Ti composition. Type 2 and 3 chromitites have sub economic size as a source of chromite ore. The geometrical relationships of type-3 deposits indicate "syngenetic" deposition of chromitite in equilibrium with host dunite, or late "epigenetic" emplacement of chromitite within solid dunite [47]. PGM in the syngenetic type chromitite mostly form small inclusions in chromite crystals. PGM in the epigenetic chromitites fill interstitial space between chromite grains and form huge aggregates which are the main source for the famous Uralian placers.

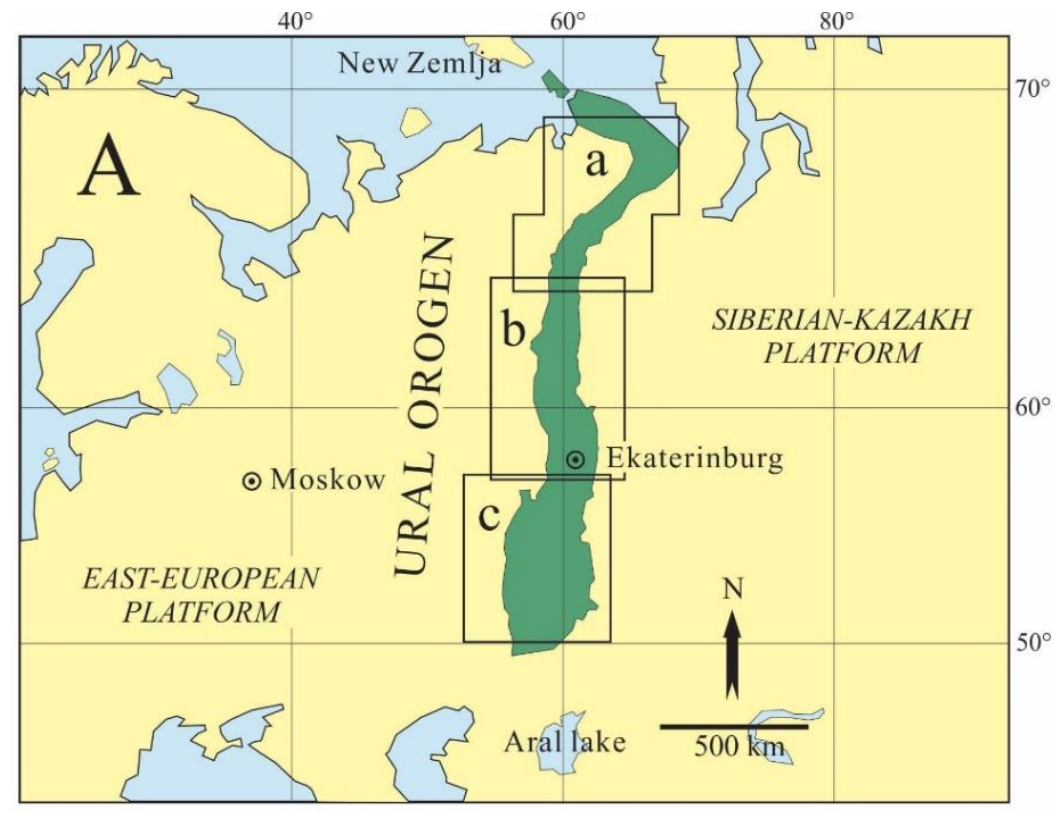

Figure 1. Cont. 


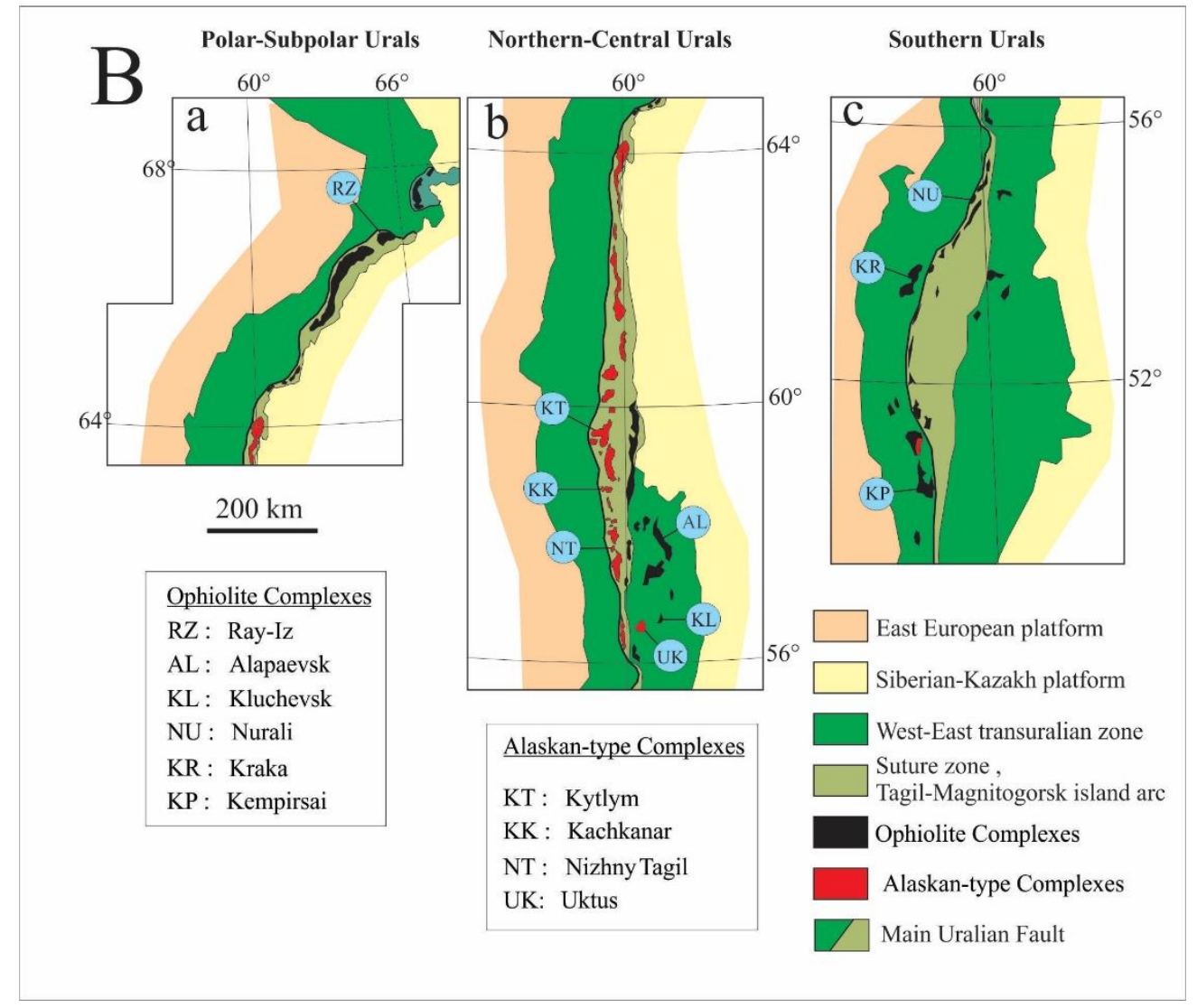

Figure 1. (A) The Ural orogen. (B) Simplified geological map of the Polar, Central, and Southern Urals, showing the location of the complexes hosts the studied chromitites.

Type-3 chromite compositions reported in Table 1 refer to "syngenetic" chromitites which better reflect conditions of chromitite-dunite co-precipitation from the Alaskan primitive magma, at high temperature. Overview of the PGE geochemistry $[24,28,39,40,44,48,49]$ indicates that the chromitites are characterized by distinctive chondrite-normalized [50] PGE patterns, showing alternative predominance of Os-Ir-Ru (Figure 2A), and Rh-Pt-Pd (Figure 2B,C) in podiform and banded chromitites associated with ophiolites, or a marked Pt-Ir specialization with Ru negative anomaly in those within Alaskan-type intrusions (Figure 2D). 
Table 1. Geologic classification of chromite deposits of the Urals.

\begin{tabular}{|c|c|c|c|c|c|c|c|c|c|}
\hline & $\mathrm{TiO}_{2}$ & $\mathrm{Al}_{2} \mathrm{O}_{3}$ & $\mathrm{Cr}_{2} \mathrm{O}_{3}$ & $\# \mathrm{Cr}$ & $\# \mathrm{Fe}^{2}$ & $\# \mathrm{Fe}^{3}$ & Host Rock & Magma Type & Geological Setting \\
\hline \multicolumn{10}{|c|}{ Type-1, Mantle.hosted ophiolitic chromitite } \\
\hline Ray-Iz high-Cr (8) & 0.10 & 9.69 & 59.19 & 0.80 & 0.33 & 0.05 & $\mathrm{~Hz}-\mathrm{D}$ & IA-bon & SSZ \\
\hline Kempirsai MOF high-Cr (21) & 0.16 & 9.76 & 59.69 & 0.80 & 0.30 & 0.05 & Hz-D & IA-bon & SSZ \\
\hline Kraka high-Cr (5) & 0.17 & 12.84 & 55.76 & 0.74 & 0.31 & 0.06 & L-H-(D) & picritic-thol & MOR/BA? \\
\hline Kluchevsk high-Cr (7) & 0.19 & 11.62 & 55.94 & 0.77 & 0.38 & 0.06 & D-tz & IA-bon & SSZ \\
\hline Alapaevsk high-Cr (5) & 0.21 & 10.55 & 57.78 & 0.79 & 0.38 & 0.07 & $\mathrm{~Hz}-\mathrm{D}$ & & SSZ \\
\hline Alapaevsk high-Al (9) & 0.27 & 22.42 & 44.63 & 0.57 & 0.31 & 0.06 & L-H-(D) & MORB & MOR? \\
\hline \multicolumn{10}{|c|}{ Type-2, Banded chromitite in supra-Moho cumulates of ophiolites } \\
\hline Kempirsai BAT (9) & 0.08 & 26.67 & 40.99 & 0.51 & 0.29 & 0.05 & $\mathrm{D}$ & MORB & MOR \\
\hline Kempirsai TAG (3) & 0.30 & 25.68 & 38.60 & 0.50 & 0.37 & 0.07 & $\mathrm{D}$ & MORB & MOR \\
\hline Kempirsai STEP (7) & 0.53 & 28.50 & 36.33 & 0.46 & 0.36 & 0.06 & D-T & MORB & MOR \\
\hline Nurali low-Ti (7) & 0.08 & 28.70 & 36.88 & 0.46 & 0.35 & 0.06 & D-Wr & picritic-thol & $\mathrm{CM}$ \\
\hline Nurali high-Ti (5) & 0.77 & 19.73 & 33.22 & 0.53 & 0.56 & 0.19 & Wr-Cpx & Fe-thol & $\mathrm{CM}$ \\
\hline \multicolumn{10}{|c|}{ Type-3, Chromitite lenses in Alaskan-type zoned intrusions } \\
\hline Kachkanar (5) & 0.50 & 7.64 & 50.60 & 0.82 & 0.47 & 0.17 & $\mathrm{D}$ & ankar & IA \\
\hline Nizhny Tagil (18) & 0.44 & 7.45 & 51.30 & 0.82 & 0.44 & 0.17 & $\mathrm{D}$ & ankar & IA \\
\hline Kytlym (8) & 0.77 & 10.57 & 42.13 & 0.73 & 0.47 & 0.23 & $\mathrm{D}$ & ankar & IA \\
\hline Kytlym Butyrin vein (6) & 1.84 & 6.30 & 30.12 & 0.76 & 0.71 & 0.43 & Cpx & IPB? & IA \\
\hline Uktus S-dunite (10) & 0.61 & 12.91 & 48.26 & 0.72 & 0.42 & 0.12 & $\mathrm{D}$ & ankar & CM? \\
\hline Uktus W-dunite (2) & 0.55 & 11.45 & 50.70 & 0.75 & 0.50 & 0.11 & $\mathrm{D}$ & ankar & CM? \\
\hline Uktus N-dunite (7) & 1.00 & 11.66 & 40.53 & 0.69 & 0.54 & 0.22 & $\mathrm{D}$ & ankar & CM? \\
\hline
\end{tabular}

Note: Column 1: Chromitite type, locality, number of samples (n). MOF = Main Ore Field, BAT = Batamshinsk, TAG = Tagashasai, STEP = Stepninsk; \#Cr $=$ Cr $/(\mathrm{Cr}+\mathrm{Al})$, $\# \mathrm{Fe}^{2}=\mathrm{Fe}^{2} /\left(\mathrm{Fe}^{2}+\mathrm{Mg}\right), \# \mathrm{Fe}^{3}=\mathrm{Fe}^{3} /\left(\mathrm{Fe}^{3}+\mathrm{Cr}+\mathrm{Al}\right)$, at \%; host rock: $\mathrm{H}=$ harzburgite; $\mathrm{D}=$ dunite; $\mathrm{L}=$ lherzolite; $\mathrm{Wr}=$ wherlite; $\mathrm{Px}=$ pyroxenite; $\mathrm{Cpx}=$ clinopyroxenite; $\mathrm{T}=$ troctolite.; magma type: IA-bon = island arc boninite; thol = tholeiite; ankar = ankaramite; IPB = intra-plate basalt; setting (inferred from host-rock petrology): SSZ = supra-suduction zone; $\mathrm{MOR}=$ mid oceanic ridge; $\mathrm{FA}=$ fore arc; $\mathrm{BA}=$ back arc; $\mathrm{IA}=$ island arc; $\mathrm{CM}=$ continental margin. 

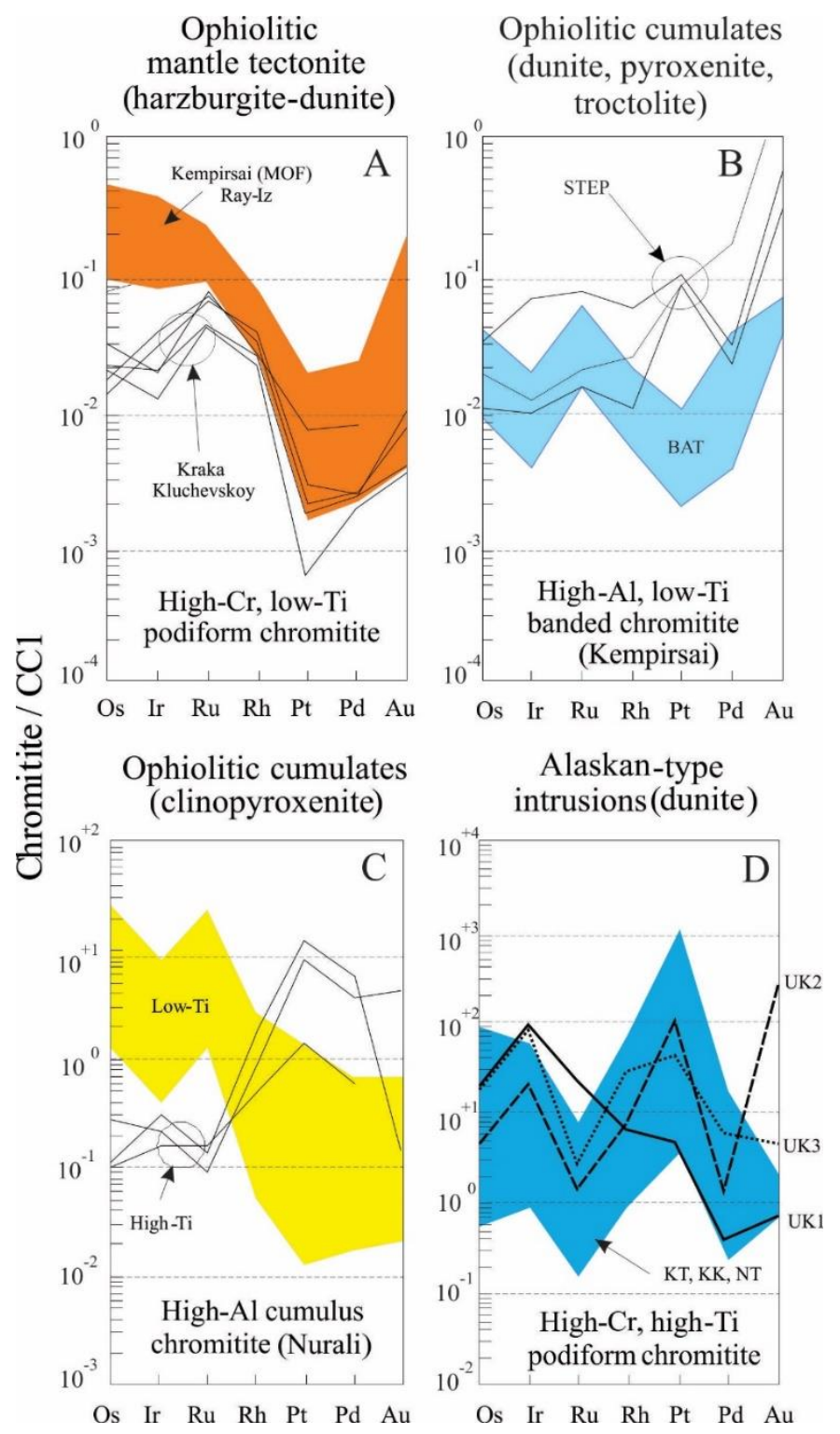

Figure 2. Platinum-group elements (PGE) chondrite [50] normalized patterns for selected chromitites of the Urals. (A) PGE distribution in mantle hosted ophiolitic chromitites, MOF $=$ main ore field. (B) PGE distribution in banded chromitites from Kempirsai ophiolite, STEP = Stepninsk deposit, BAT = Batamshinsk deposit. (C) PGE distribution in cumulus chromitites from the Nurali complex. (D) PGE distribution in Alaskan-type chromitites from Uktus (UK), Kytlym (KT), Kachkanar (KK) and Nizhny Tagil (NT) complexes. See the text for the data source.

\section{Distribution and Mineralogy of the PGM Inclusions}

The amount of PGM inclusions varies greatly in both the ophiolitic and Alaskan-type chromitites of the Urals, displaying extremely irregular distribution even at the scale of single hand samples. For example, in [27] it was reported that about 30\% of the polished sections investigated from the mantle-hosted chromitites of Kempirsai contain relatively abundant PGM, whereas only a few grains were observed in the remainder. About 100 PGM grains were identified in 23 samples from three chromite deposits of the Ray-Iz mantle tectonite, however only $10 \%$ of the samples showed significant PGM enrichment [22]. Most samples from Kraka, Kluchevsk, Alapevsk and the banded chromitite in the supra-moho cumulates of Kempirsai display very low contents of PGM, with a maximum frequency of 4-5 grains per $6.5 \mathrm{~cm}^{2}[27,38,40,44]$. In contrast, more than 400 PGM grains have been found in 
chromitite bands in the supra-moho cumulates of the Nurali ophiolite, with a maximum frequency of 8-10 grains per $6.5 \mathrm{~cm}^{2}$ [39]. About $50 \%$ of the chromitite samples investigated from the Alaskan-type complexes were found to contain disseminated PGM. Chromitites from Nizhny-Tagil (18 samples) and Kachkanar (4 samples) contain PGM with maximum contents of 50 and 8 grains, respectively [19]. About 420 PGM grains were analyzed in 15 samples from the Uktus and Kytlym zoned intrusions, with a maximum frequency of 12 grains per $6.5 \mathrm{~cm}^{2}$ in the richest samples of Kytlym [23,24,41]. The mineralogy of PGM in the Ural chromitites includes alloys, sulfides, sulfarsenides, arsenides, tellurides, antimonides, and accessory base metal (BM) minerals (sulfides, arsenides, oxides, alloys) containing minor amounts of PGE. Accessory Au and Ag phases have also been reported from various chromitites. A list of known and unknown PGM identified in the chromitites of the Urals is given in Table 2.

Table 2. Platinum Group Minerals, and accessory PGE-bearing base-metal minerals identified in chromitites of the Urals.

\begin{tabular}{|c|c|}
\hline Mineral Species & Ideal Composition \\
\hline Sulfides & $\begin{array}{l}\text { Laurite }(\mathrm{RuOsIr}) \mathrm{S}_{2} \text {, Erlichmanite }(\mathrm{OsRuIr}) \mathrm{S}_{2}, \mathrm{Kashinite} \mathrm{Ir}_{2} \mathrm{~S}_{3} \text {, Bowieite } \\
\mathrm{Rh}_{2} \mathrm{~S}_{3} \text {, Cuproiridsite } \mathrm{CuIr}_{2} \mathrm{~S}_{4}, \text { Cuprorhodsite } \mathrm{CuRh}_{2} \mathrm{~S}_{4}, \text { Malanite } \\
\mathrm{CuPt}_{2} \mathrm{~S}_{4} \text {, Cooperite }(\mathrm{PtPdNi}) \mathrm{S} \text {, Braggite }(\mathrm{PtPdNi}) \mathrm{S} \text {, Vysotskite (PtPtNi)S, } \\
\text { unknown Ir-Rh-Ni-Fe thiospinels and monosulfides; }\end{array}$ \\
\hline PGE-bearing Base Metal Sulfides & $\begin{array}{l}\text { Ru-Pentlandite }(\mathrm{NiFeRu})_{9} \mathrm{~S}_{8} \text {, Rh-Pentlandite }(\mathrm{NiFeRh})_{9} \mathrm{~S}_{8}, \text { Pt-pyrrhotite } \\
(\mathrm{FePt})_{1-x} \mathrm{~S} \text {, Ir-Rh-Heazlewoodite }(\mathrm{NiIrRh})_{3} \mathrm{~S}_{2}\end{array}$ \\
\hline Sulfarsenides, Arsenides & $\begin{array}{l}\text { Irarsite IrAsS, Osarsite OsAsS, Ruarsite RuAsS, Hollingworthite RhAsS, } \\
\text { Platarsite PtAsS, Omeiite OsAs, } \text {, Ruthenarsenite (RuNi)As, } \\
\text { Cherepanovite RhAs, Zaccariniite RhNiAs, Sperrylite PtAs } 2 \text {, unknown } \\
\text { Ir-Rh-Os arsenides }\end{array}$ \\
\hline PGE-bearing Base Metal Arsenides & Rh-Orcelite $(\mathrm{NiIrRh})_{5-\mathrm{x}} \mathrm{As}_{2}, \mathrm{Rh}-\mathrm{Maucherite}(\mathrm{NiIrRh})_{11} \mathrm{As}_{8}$ \\
\hline Alloys & $\begin{array}{l}\text { Osmium, Iridium, Ruthenium, Rutheniridosmine }(\mathrm{OsIrRu}) \text {, Platinum, } \\
\text { Isoferroplatinum } \mathrm{Pt}_{3} \mathrm{Fe},\left(\mathrm{Pt}_{2.5}(\mathrm{FeNiCu})_{1.5} \text {, Tetraferroplatinum } \mathrm{PtFe} \text {, }\right. \\
\mathrm{Pt}(\mathrm{FeNiCu}) \text {, Ferronickelplatinum } \mathrm{Pt}_{2} \mathrm{FeNi} \text {, Tulameenite } \mathrm{Pt}_{2} \mathrm{FeCu}, \\
\text { Potarite } \mathrm{HgPd} \text {, unknown } \mathrm{Pt}-\mathrm{Cu}, \mathrm{Pt}-\mathrm{Pd}-\mathrm{Cu}-\mathrm{Ni}-\mathrm{Fe}, \mathrm{Ru}-\mathrm{Ir}-\mathrm{Os}-\mathrm{Fe}-\mathrm{Ni}\end{array}$ \\
\hline PGE-bearing Base Metal Alloys & Ru-Awaruite NiFeRu, Garutiite NiFeIr \\
\hline Tellurides, Antimonides & $\begin{array}{l}\text { Merenskyite } \mathrm{PdTe}_{2} \text {, Tolvkite IrSbS, Geversite } \mathrm{PtSb}_{2} \text {, Stibiopalladinite } \\
\mathrm{Pd}_{5+\mathrm{x}} \mathrm{Sb}_{2-\mathrm{x}} \text {, unknown Ir-Sb, } \mathrm{Pt}-\mathrm{Fe}-\mathrm{Sb}, \mathrm{Rh}-\mathrm{Te}, \mathrm{Rh}-\mathrm{Sb}\end{array}$ \\
\hline PGE-bearing oxides & Unknown $\mathrm{Ru}-\mathrm{Os}-\mathrm{Ir}-\mathrm{Fe}-\mathrm{Ni}-\mathrm{O}$ \\
\hline
\end{tabular}

Most authors have divided the PGM into two genetically distinct categories, based on their textural relations: (1) the "primary" PGM occurring enclosed in fresh chromite far from cracks and alteration zones, and (2) the "secondary" PGM being invariably associated with low-temperature assemblages, either included in the ferrianchromite rim of chromite grains, or in the interstitial silicate matrix (serpentine, chlorite, talc). In this overview we have focused our attention on the paragenetic characters of the primary PGM occurring enclosed in fresh chromite thereby reflecting high temperature conditions of formation, having been preserved from low-temperature alteration. The ophiolitic chromitites, as a whole, display predominance of Os-Ir-Ru minerals (IPGM) over Rh-Pt-Pd (PPGM) (Figure 3A), in agreement with the dominant negative trend of the PGE profiles (Figure 2A-C). The IPGM population mainly consists of Ru-Os disulfides of the laurite-erlichmanite series, cuproiridsite, and various Ir-Ni thiospinels and monosulfides occurring in primary inclusions. The sulfides are accompanied by decreasing amounts of Os-Ir alloys, As-bearing phases (irarsite), and BM minerals containing detectable amounts of PGE (mainly Ru-pentlandite) (Figure 3B), which may be found in both primary and secondary assemblages.

The small proportion ( $6 \%$ ) of PPGM reflects the occurrence of Pt and Pd phases (sperrylite, stibiopalladite, tetraferroplatinum, potarite, unknown $\mathrm{Pt}-\mathrm{Pd}-\mathrm{Cu}-\mathrm{Ni}-\mathrm{Fe}$ alloys) in chromitites from the uppermost cumulus layers of Nurali and Kempirsai $[39,45]$, which distinguish for nearly flat to markedly positive chondritic profiles. Particularly numerous is the category "Ox" including rare 
PGE oxydes and a great variety of unknown O-bearing compounds consisting of native Ru-Os-Ir intermixed with Fe-oxide and relicts of sulfide. These grains are interpreted to have derived from partial to complete desulfidation of primary PGM during serpentinization [21]. The Alaskan-type chromitites contain high proportion (81\%) of PPGM in front of 19\% IPGM. Consistent with the saw-like trend typical of most PGE profiles (Figure 2D), the PGM assemblage is characterized by the predominance of Pt- and Ir-phases, and paucity of Ru and Pd PGM [15,24,41,48,50]. PGE alloys are by far the most abundant PGM phase, accompanied by decreasing amounts of sulfides, As-PGM, BM minerals, and Te-, Sb-, and Hg-based PGM (Figure 3B). The Pt-Fe alloys isoferroplatinum and tetraferroplatinum, along with iridium, osmium, erlichmanite, kashinite, cooperite-braggite, $\mathrm{Ir}-\mathrm{Rh}-\mathrm{Pt}$ thiospinels (cuproiridsite, cuprorhodsite, malanite), and unknown Ir-Ni sulfides (Table 2) are the major components of primary inclusions in fresh chromite. Euhedral laurite crystals have also been reported as primary inclusion in chromitites of the Uktus complex. Other PGM such as tulameenite, $\mathrm{Cu}-\mathrm{Pd}-\mathrm{Pt}$ alloys, potarite, irarsite, geversite, tolovkite, unknown $\mathrm{Rh}-\mathrm{Te}$ (Table 2) are found exclusively as replacement of primary PGM, or associated with alteration assemblages (ferrianchromite, chlorite, serpentine) indicating that they formed in a low-temperature post-magmatic stage [23,24].

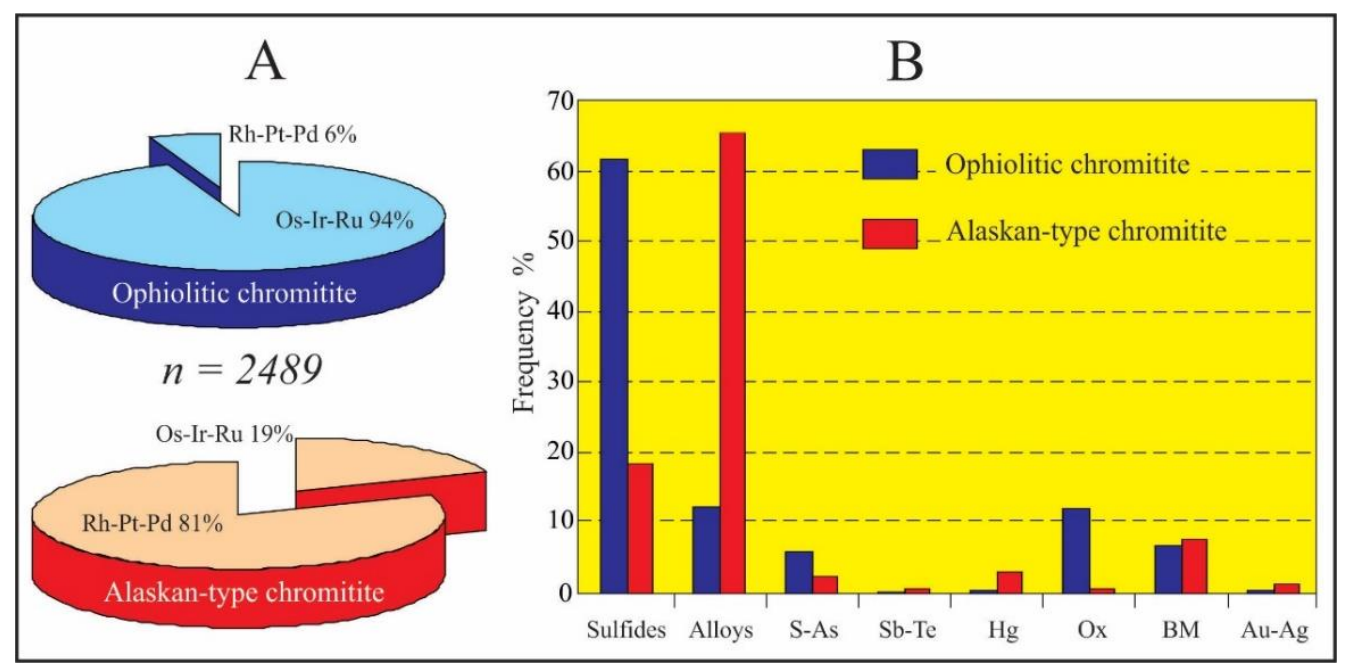

Figure 3. Platinum group minerals (PGM) abundance in the ophiolitic and Alaskan-type chromitites of the Urals. (A) Distribution of the PGM based on the dominant PGE. (B) Frequency of the PGM according to their mineralogical species.

\section{Primary PGM in Ophiolitic Chromitites}

\subsection{Paragenetic Assemblages of PGM as Function of Sulfur Fugacity}

The primary PGM inclusions in ophiolitic chromitites are generally less than $20 \mu \mathrm{m}$ in size, and may occur either as solitary, polygonal crystals, or composite grains consisting of two or more PGM, with or without BM sulfide and silicate (Figure 4). Representative compositions of the PGM are given in Table 3. The paragenesis and composition of these PGM can be modelled according to a sequence of crystallization events controlled by relative stability of PGE alloys and sulfides as function of sulfur fugacity, $\mathrm{f}\left(\mathrm{S}_{2}\right)$, and temperature, $\mathrm{T}{ }^{\circ} \mathrm{C}$ (Figure $5[28,51,52]$ ). In the mantle-hosted chromitites of Kempirsai and Ray-Iz, as well as in the cumulus chromitite of Nurali, primary PGM disulfides, with compositions ranging continuously between laurite $\left(\mathrm{RuS}_{2}\right)$ and erlichmanite $\left(\mathrm{OsS}_{2}\right)$, coexist with primary Os-Ir alloys characterized by Ru-poor compositions $[20,28,39,53]$. The paragenesis indicates that the $f\left(S_{2}\right)$ was initially close to the threshold for the formation of laurite $\left(R u+S_{2}=R u S_{2}\right)$ coexisting with Os-Ir alloys. Increase of $f\left(S_{2}\right)$ with decreasing temperature results in the progressive stabilization of erlichmanite, various Ir-Ni sulfides, and Ni-Fe sulfides (Figure 5). Since an increment in $f\left(S_{2}\right)$ favours entering of Os in laurite [12], early laurite coexisting with Os-Ir alloys will have relatively high 
$\mathrm{Ru} /$ Os ratio comprised between $\mathrm{Ru}_{100}$ and $\mathrm{Ru}_{72} \mathrm{Os}_{28}$, the latter corresponding to the unfractionated chondritic composition [53]. Further increase in $f\left(S_{2}\right)$ will cause progressive decrease of the Ru/Os ratio well below the chondritic value [53], and the composition of laurite will enter the erlichmanite field (Figure 4E-G). At Nurali, several laurite grains are zoned showing Os enrichment in the rim (Figure 4D). This has been interpreted as evidence supporting that the increase in $\mathrm{f}(\mathrm{S} 2)$ also accompanies fractional crystallization of chromitite in the cumulus pile of ophiolites [39]. The sulfarsenides and arsenides frequently appear as small particles attached to the external border of the Ir-Ni sulfides (Figure $4 \mathrm{H}$ ), or overgrowing primary Os-Ir alloy crystals (Figure 4I). Although representing very accessory members of the primary assemblage of PGM inclusions, the crystallization of primary As-based PGM requires a relative increase of arsenic-fugacity in the latest stage of PGM precipitation at high temperature. Based on morphological considerations it would appear that the PGE alloys and sulfides were trapped in crystallizing chromite as solid particles or, at least in part, as liquid droplets adherent to solid crystals, for example, the Ru-arsenide enveloping the Os-Ir alloy (Figure 4I). This observation requires that the whole sequence of PGM crystallization alloy-sulfide-arsenide must have taken place in high thermal range between the crystallization temperature of Os-poor laurite $\left(\sim 1100^{\circ} \mathrm{C}\right)$, and the solidus of chromite as the lower limit (see arrow T1 in Figure 5). However, some authors [27] have presented $\mathrm{f}\left(\mathrm{S}_{2}\right) / \mathrm{T}{ }^{\circ} \mathrm{C}$ lines trending along a much wider thermal gradient (see arrow T2 in Figure 5), well below the chromite solidus, implying that certain PGM might have split off the chromite in the subsolidus under long-lasting annealing conditions.
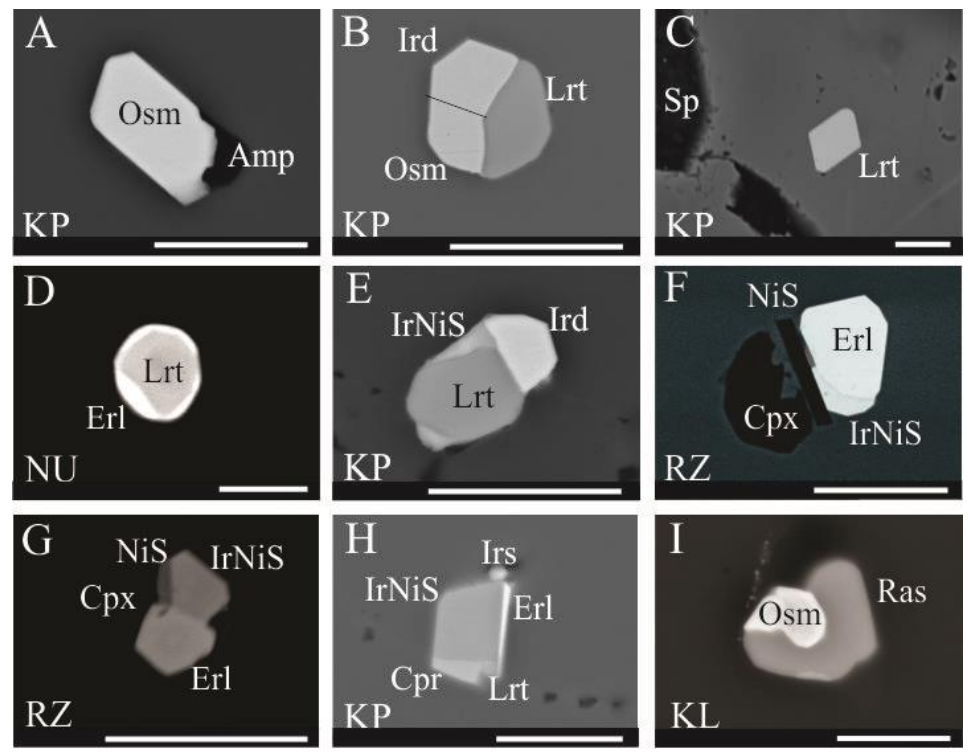

Figure 4. Back-scattered electron images of selected PGM included in chromite from the ophiolitic chromitites of the Urals. (A) Osmium associated with amphibole. (B) Bi-phase PGM composed of osmium and laurite. (C) single phase laurite. (D) Laurite rimmed by erlichmanite. (E) Complex PGM composed of laurite, iridium and an unnamed Ir and Ni sulfide. (F) Composite grain of erlichmanite, unnamed Ir and Ni sulfide, Ni sulfide in contact with clinopyroxene. (G) PGM consisting of erlichmanite, unnamed Ir and Ni sulfide and clinopyroxene. $(\mathbf{H})$ Complex grain of laurite, erlichmanite, cuprorhodsite, unnamed Ir and Ni sulfide, and irarsite. (I) Bi-phase PGM composed of osmium and ruthenarsenide. Scale bar $=10 \mu \mathrm{m}$. Abbreviations: Osm = osmium, Amp = amphibole, Ird = iridium, Lrt = laurite, Sp = serpentine, Erl = erlichmanite, IrNiS = unnamed Ir and Ni sulfide, $\mathrm{Cpx}=$ clinopyroxene, $\mathrm{NiS}=\mathrm{Ni}$ sulfide, $\mathrm{Cpr}=$ cuproiridsite, $\mathrm{Irs}=$ irarsite, $\mathrm{Ras}=$ ruthenarsenide. Abbreviations for the studied chromitites see Figure 1. 
Table 3. Electron microprobe analyses (wt \%) of PGM in ophiolitic chromitites of the Urals.

\begin{tabular}{|c|c|c|c|c|c|c|c|c|c|c|c|c|c|c|}
\hline $\begin{array}{l}\text { Sample } \\
\text { Locality }\end{array}$ & PGM & Figure & Os & Ir & $\mathbf{R u}$ & $\mathbf{R h}$ & $\mathbf{P t}$ & $\mathbf{P d}$ & $\mathrm{Fe}$ & $\mathrm{Ni}$ & $\mathrm{Cu}$ & $S$ & As & Tot \\
\hline Kempirsai & osmium & $4 \mathrm{~A}$ & 89.43 & 5.51 & 1.51 & 0.01 & 0.00 & 0.00 & 1.27 & 1.02 & 0.17 & 0.41 & 1.20 & 100.53 \\
\hline Kempirsai & iridium & $4 \mathrm{~B}$ & 32.08 & 64.53 & 0.56 & 0.47 & 0.74 & 0.09 & 0.41 & 0.11 & 0.00 & 0.00 & 0.00 & 98.99 \\
\hline Kempirsai & osmium & $4 \mathrm{~B}$ & 53.99 & 42.98 & 0.99 & 0.08 & 0.00 & 0.00 & 0.29 & 0.00 & 0.00 & 0.08 & 0.00 & 98.41 \\
\hline Kempirsai & laurite & $4 \mathrm{~B}$ & 15.91 & 8.30 & 43.11 & 0.00 & 0.00 & 0.20 & 0.12 & 0.00 & 0.00 & 33.71 & 0.00 & 101.35 \\
\hline Kempirsai & laurite & $4 \mathrm{C}$ & 7.39 & 6.91 & 46.58 & 1.12 & 0.00 & 0.69 & 0.71 & 0.27 & 0.18 & 34.14 & 1.17 & 99.16 \\
\hline Kempirsai & laurite & $4 \mathrm{C}$ & 7.35 & 6.87 & 45.61 & 1.18 & 0.08 & 0.44 & 0.67 & 0.30 & 0.15 & 37.16 & 1.05 & 100.86 \\
\hline Kempirsai & iridium & $4 \mathrm{E}$ & 34.19 & 37.28 & 8.66 & 0.25 & 0.00 & 0.00 & 6.44 & 0.00 & 0.54 & 7.51 & 3.58 & 98.45 \\
\hline Kempirsai & cuproiridsite & $4 \mathrm{E}$ & 0.06 & 64.99 & 0.28 & 1.46 & 0.00 & 0.29 & 0.00 & 0.29 & 10.79 & 20.39 & 0.00 & 98.55 \\
\hline Kempirsai & laurite & $4 \mathrm{E}$ & 24.77 & 9.44 & 28.30 & 0.75 & 0.00 & 0.15 & 4.29 & 0.00 & 0.16 & 30.23 & 1.53 & 99.62 \\
\hline Kempirsai & laurite & $4 \mathrm{E}$ & 26.98 & 8.96 & 32.29 & 0.00 & 0.00 & 0.36 & 0.70 & 0.00 & 0.00 & 29.98 & 0.00 & 99.27 \\
\hline Kempirsai & Ir-Ni monosulfide & $4 \mathrm{H}$ & 0.00 & 43.16 & 0.00 & 0.34 & 0.00 & 0.13 & 6.81 & 18.31 & 6.81 & 25.51 & 0.00 & 101.07 \\
\hline Kempirsai & Ir-Ni monosulfide & $4 \mathrm{H}$ & 0.00 & 43.29 & 0.00 & 0.36 & 0.00 & 0.11 & 6.49 & 18.02 & 6.96 & 24.74 & 0.00 & 99.97 \\
\hline Kempirsai & Ir-Ni monosulfide & $4 \mathrm{H}$ & 0.00 & 45.89 & 0.00 & 0.46 & 0.00 & 0.08 & 5.77 & 14.28 & 7.78 & 24.82 & 0.00 & 99.08 \\
\hline Ray-Iz & laurite & & 14.51 & 7.57 & 39.21 & 1.13 & 1.37 & 0.30 & 0.04 & 0.00 & 0.00 & 34.86 & 0.00 & 98.99 \\
\hline Ray-Iz & laurite & & 4.94 & 8.17 & 50.23 & 0.86 & 0.00 & 0.00 & 0.31 & 0.23 & 0.13 & 35.45 & 0.00 & 100.32 \\
\hline Ray-Iz & laurite core & & 1.72 & 2.98 & 57.63 & 0.02 & 0.00 & 0.21 & 0.00 & 0.06 & 0.29 & 35.79 & 0.00 & 98.70 \\
\hline Ray-Iz & laurite rim & & 14.51 & 7.57 & 39.21 & 1.13 & 1.37 & 0.30 & 0.04 & 0.00 & 0.00 & 34.86 & 0.00 & 98.99 \\
\hline Ray-Iz & erlichmanite & $4 \mathrm{~F}$ & 27.88 & 12.87 & 26.83 & 0.68 & 0.00 & 0.00 & 0.02 & 0.18 & 0.16 & 30.98 & 0.00 & 99.60 \\
\hline Ray-Iz & Ir-Ni sulfide & $4 \mathrm{~F}$ & 0.04 & 44.35 & 0.00 & 1.22 & 0.96 & 0.21 & 3.93 & 18.26 & 4.52 & 26.33 & 0.12 & 99.94 \\
\hline Ray-Iz & erlichmanite & $4 \mathrm{G}$ & 45.11 & 10.71 & 13.42 & 0.06 & 0.00 & 0.04 & 0.13 & 0.11 & 0.05 & 31.50 & 0.50 & 101.63 \\
\hline Ray-Iz & Ir-Ni thiosp & $4 \mathrm{G}$ & 0.16 & 43.18 & 0.05 & 0.37 & 0.45 & 0.00 & 5.25 & 16.56 & 5.03 & 28.84 & 0.04 & 99.93 \\
\hline Ray-Iz & Ir-Ni thiospin & & 0.00 & 43.56 & 0.00 & 3.85 & 0.08 & 0.24 & 5.12 & 11.87 & 6.46 & 29.08 & 0.02 & 100.28 \\
\hline Ray-Iz & cuproiridsite & & 0.00 & 55.97 & 0.04 & 5.95 & 1.63 & 0.11 & 0.00 & 0.22 & 10.52 & 26.26 & 0.02 & 100.72 \\
\hline Kraka & laurite & & 14.26 & 6.61 & 39.13 & 0.83 & 0.00 & 0.57 & 0.00 & 0.00 & 0.08 & 36.54 & 0.99 & 99.01 \\
\hline Kraka & laurite & & 16.40 & 6.15 & 41.65 & 0.12 & 0.00 & 0.00 & 0.20 & 0.24 & 0.02 & 34.87 & 0.00 & 99.65 \\
\hline Nurali & laurite core & $4 \mathrm{D}$ & 19.10 & 5.41 & 39.92 & 0.00 & 0.00 & 0.00 & 0.36 & 0.35 & 0.00 & 34.88 & 0.00 & 100.02 \\
\hline Nurali & erlichmanite rim & $4 \mathrm{D}$ & 64.18 & 2.01 & 9.01 & 0.21 & 0.00 & 0.00 & 0.09 & 0.02 & 0.00 & 26.10 & 0.00 & 101.62 \\
\hline Kluchevsk & rutheniridosmine & $4 \mathrm{I}$ & 54.55 & 16.02 & 24.76 & 0.62 & 0.00 & 0.29 & 0.00 & 2.29 & 0.00 & 0.00 & 1.88 & 100.41 \\
\hline Kluchevsk & ruthenarsenite & $4 \mathrm{I}$ & 7.49 & 1.29 & 40.18 & 1.41 & 0.57 & 0.54 & 0.28 & 5.91 & 0.00 & 0.02 & 41.32 & 99.01 \\
\hline
\end{tabular}




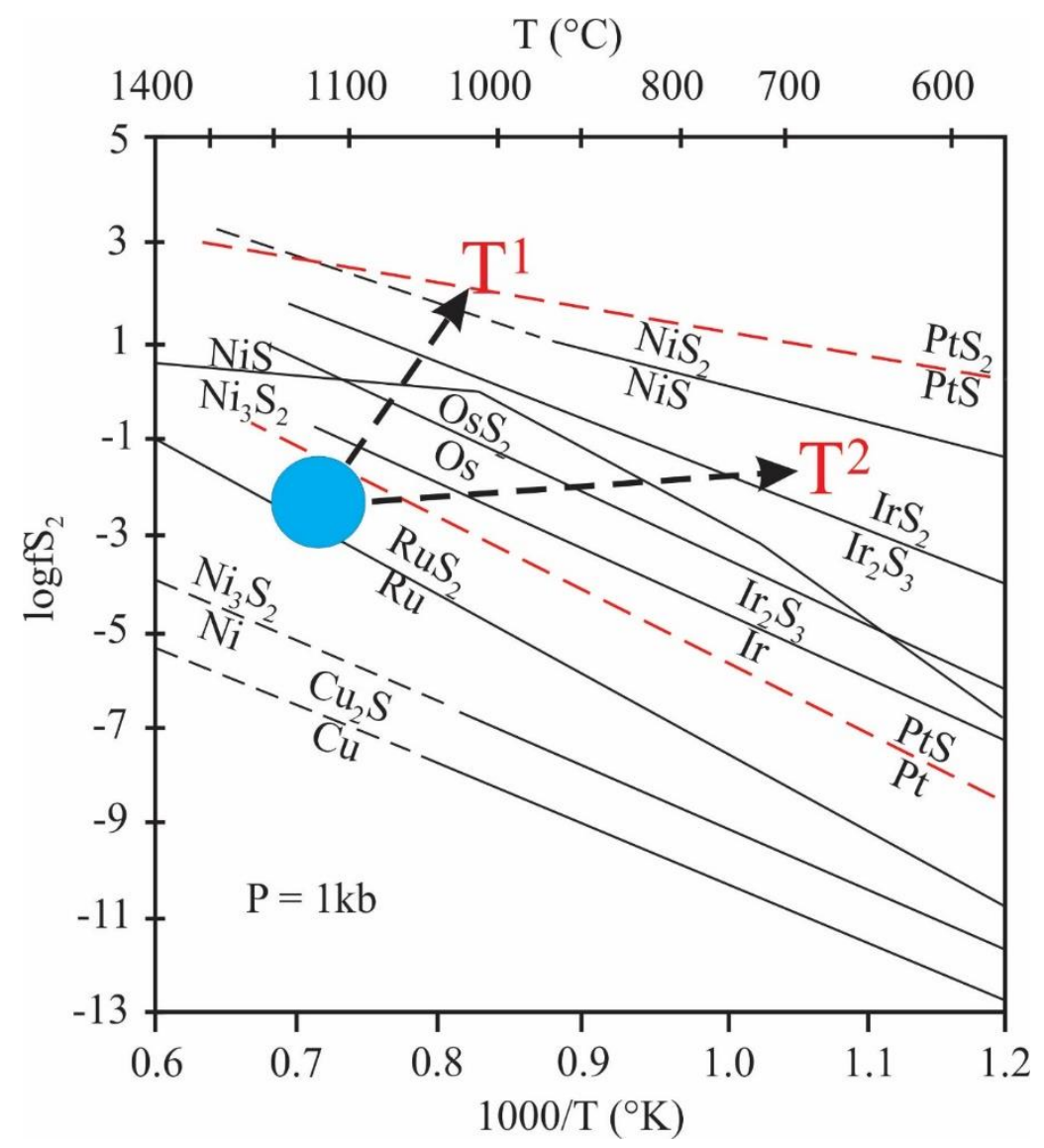

Figure 5. Metal-sulfide equilibrium curves for $\mathrm{Ru}, \mathrm{Os}, \mathrm{Ir}, \mathrm{Pt}, \mathrm{Ni}$, and $\mathrm{Cu}$ as function of sulfur fugacity and temperature. Two different possible trends of the PGM precipitation are given [28,52].

\subsection{Relationships with Chromite Composition}

The oxygenthermobarometry $[46,54]$ based on the olivine-spinel equilibrium [55] shows that chromitites of the Urals equilibrated in a wide range from 1510 to $590{ }^{\circ} \mathrm{C}$. Discarding unrealistic values above $1400{ }^{\circ} \mathrm{C}$ and below $700{ }^{\circ} \mathrm{C}$, most samples (e.g., Kempirsai) plot between 1400 and $700{ }^{\circ} \mathrm{C}$, following a trend of increasing $\mathrm{Fe}^{3} /\left(\mathrm{Fe}^{3}+\mathrm{Fe}^{2}\right)$ and $\Delta \log \left(\mathrm{O}_{2}\right)$ with decreasing temperature (Figure $6 \mathrm{~A}$ ) suggesting that the increase of $\mathrm{fO}_{2}$ continued in the subsolidus [27]. Adjustment of the $\mathrm{Fe}^{3} /\left(\mathrm{Fe}^{3}+\mathrm{Fe}^{2}\right)$ ratio occurs by oxidation of $\mathrm{Fe}^{2}$ inside the chromite itself as indicated by the negative correlation between $\mathrm{Fe}^{3} /\left(\mathrm{Fe}^{3}+\mathrm{Fe}^{2}\right)$ and $\mathrm{Fe}^{2} /\left(\mathrm{Fe}^{2}+\mathrm{Mg}\right.$ ) (Figure $6 \mathrm{~B}$ ).

The assemblage of PGM inclusions indicates that the $f\left(S_{2}\right)$ was forced to increase up to values suitable for the stabilization of high-energy PGM sulfides [56], and/or sulfidation of those PGE that were still residing in the chromite as atomic clusters [27]. The temperatures calculated for chromitites of Kraka are sensibly higher than those of Kempirsai $\left(1310-1090{ }^{\circ} \mathrm{C}\right)$. In these chromitites, laurite shows limited $\mathrm{Ru}-\mathrm{Os}$ substitution, and occurs as isolated euhedral crystals, sometimes associated with primary mafic silicates, mainly clinopyroxene. The Ir-Ni sulfides are conspicuously absent, indicating precipitation of the PGM at lower sulfur fugacity compared with Kempirsai and Ray-Iz [40]. Composition and textural characters of these laurites are totally similar to the laurite grain in Figure 4C, supporting that these grains formed in the magma prior to chromite crystallization, and escaped re-equilibration at low temperature. In conclusion, the data presented here support that laurite can precipitate from the magma at relatively low $\mathrm{fS}_{2}$, and is enclosed in the chromite as a solid particle. Under a high cooling-rate (line $\mathrm{T} 1$ in Figure 5) the $\mathrm{fS}_{2}$ increases rapidly, stabilizing the expected sequence of PGM sulfides prior to the crystallization of chromite. In the lack of annealing, there will be 
no reequilibration-adjustment of the chromite composition and limited chance for the formation of PGM inclusions in the subsolidus.

On the contrary, post-magmatic equilibration under slow cooling-rate, as it was the case in the Kempirsai chromite deposits, will favour formation of a high number of PGM inclusions characterized by a variegate composition.
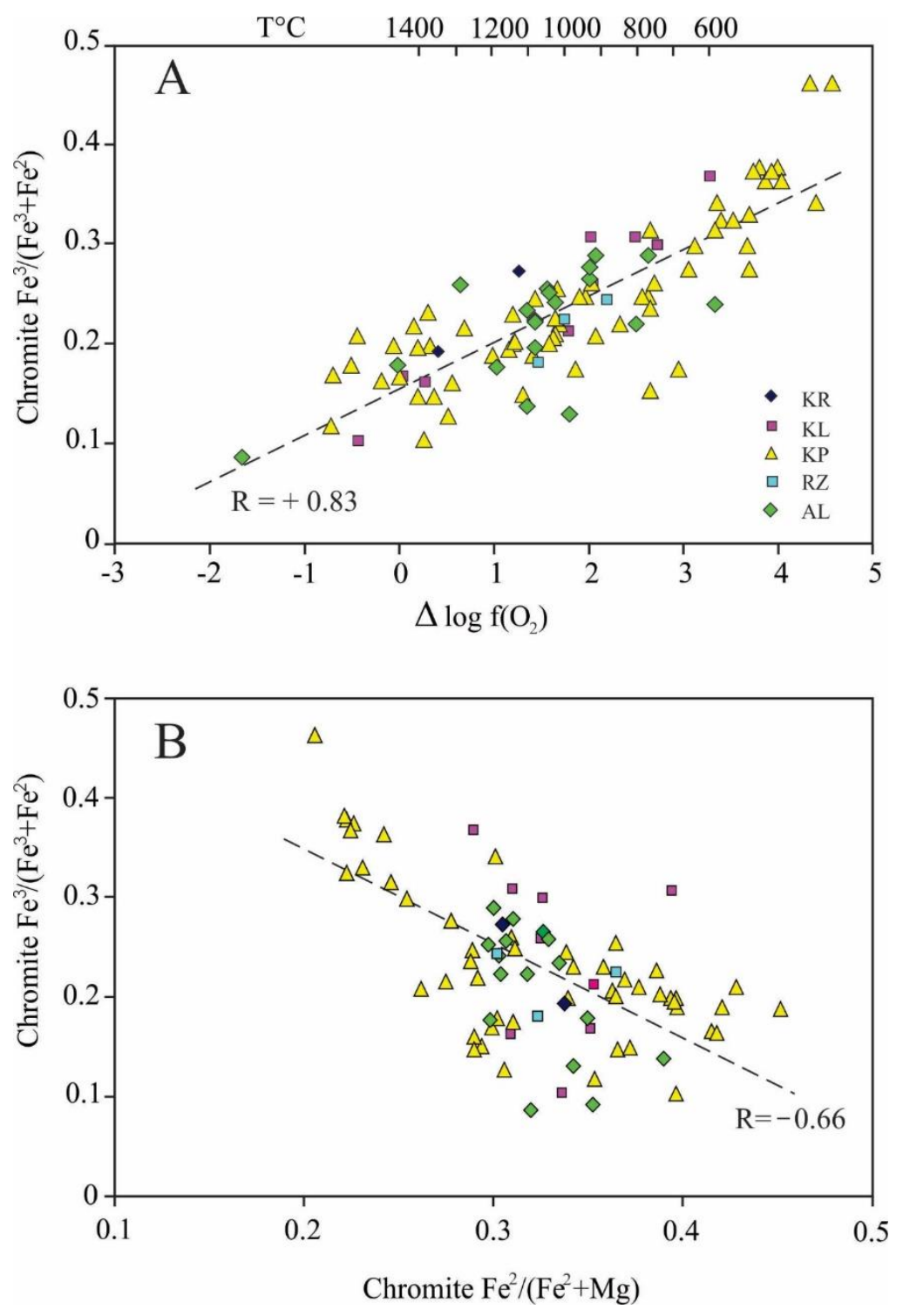

Figure 6. (A) Variation of the chromite oxidation ratio $\left[\mathrm{Fe}^{3} /\left(\mathrm{Fe}^{3}+\mathrm{Fe}_{2}\right)\right]$ as function oxygen fugacity and temperature. Oxygen fugacity is expressed as deviation from the fayalite-magnetite-quartz (FMQ) buffer. The temperature scale is based on the equation $\mathrm{T}\left({ }^{\circ} \mathrm{C}\right)=\left[\Delta \log \left(\mathrm{O}_{2}\right)-5.6231\right] /-0.0039$. See Figure 1 for the abbreviation of names of ophiolite and Alaskan-type complexes. (B) Negative correlation between the oxidation ratio and the $\mathrm{\# F}^{2}$ number of chromite. See text for explanation.

\section{Primary PGM in Alaskan-Type Chromitites}

\subsection{Primary PGM and Sulfur Fugacity in Alaskan-Type Chromitites}

Primary PGM in "syngenetic" chromitites of the Urals occur as minute disseminated grains (1-35 $\mu \mathrm{m})$ enclosed in fresh chromite, as either single-phase crystals, or forming composite aggregates of more PGM, sometimes with associated silicates. 
Most common mineral assemblages and compositions of the PGM inclusions are given in Figure 7 and Table 4, respectively.
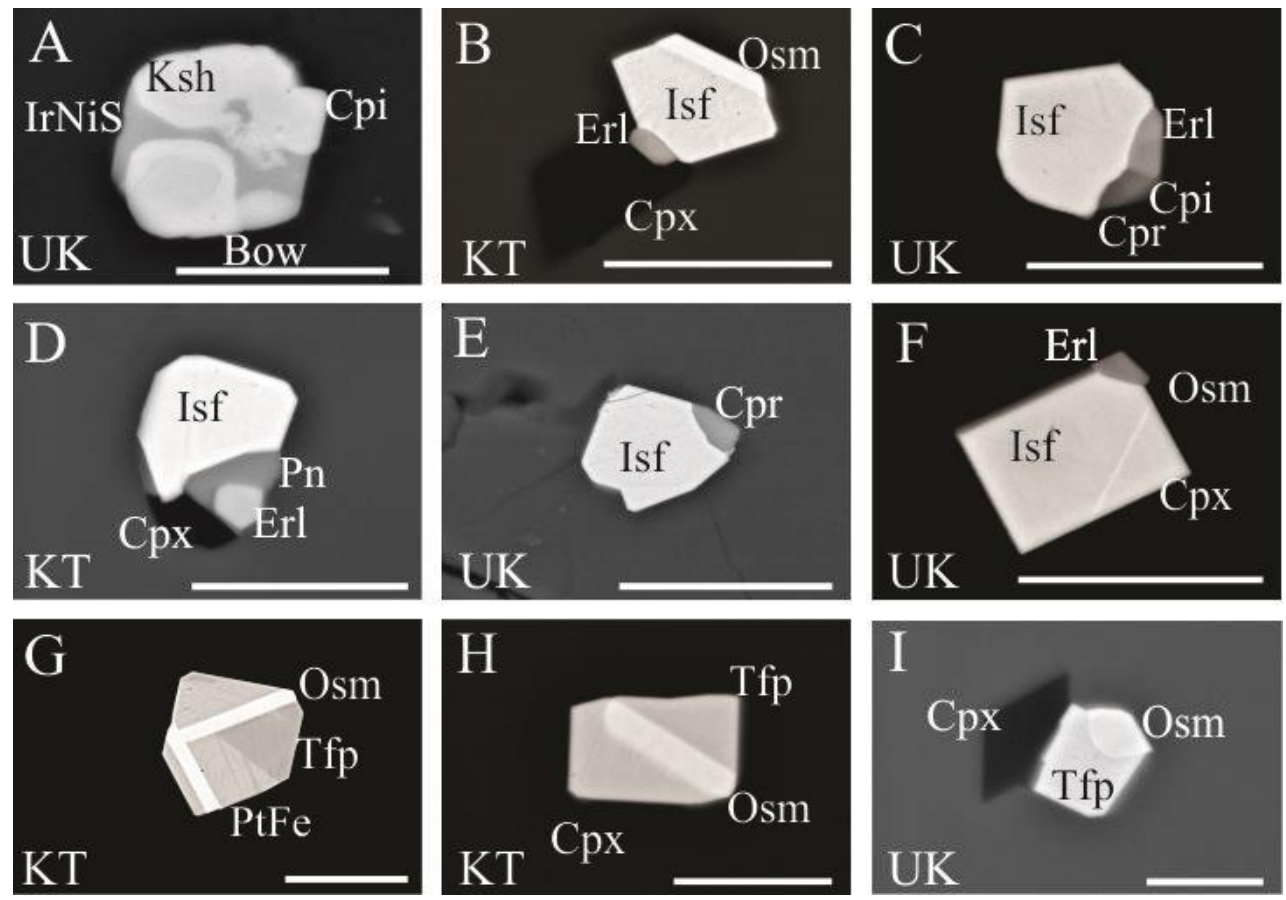

Figure 7. Back-scattered electron images of representative PGM included in chromite from the Alaskan-type chromitites of the Urals. (A) Composite crystal composed of kashinite rimmed by bowieite, cuproiridsite, and an unnamed Ir and Ni sulfide. (B) PGM consisting of isoferroplatium, erlichmanite, and osmium in contact with clinopyroxene. (C) Complex grain of isoferroplatinum, cuprorhodsite, cuproiridsite and erlichmanite. (D) Isoferroplatinum in contact with erlichmanite, pentlandite, and clinopyroxene. (E) Bi-phase grain of isoferroplatinum and cuprorhodsite. (F) PGM composed of isoferroplatinum, osmium, and erlichmanite in contact with clinopyroxene. (G) Complex crystal of tetraferroplatinum, osmium, and a $\mathrm{Pt}-\mathrm{Fe}$ alloy. (H,I) Bi-phase grains of tetraferroplatinum and osmium in contact with clinopyroxene. Scale bar $=10 \mu \mathrm{m}$. Ksh = kashinite, $\mathrm{Cpi}=$ cuproiridsite, Bow $=$ bowieite, $\mathrm{IrNiS}=$ unnamed $\mathrm{Ir}$ and $\mathrm{Ni}$ sulfide, Isf $=$ isoferroplatinum, Osm = osmium, Erl = erlichmanite, $\mathrm{Cpx}=$ clinopyroxene, $\mathrm{Cpr}=$ cuprorhodsite, $\mathrm{Pn}=$ pentlandite, $\mathrm{Tfp}=$ tetraferroplatinum, $\mathrm{PtFe}=\mathrm{Pt}-\mathrm{Fe}$ alloy. Abbreviations for the studied chromitites see Figure 1.

The predominance of $\mathrm{Pt}-\mathrm{Fe}$ alloys over sulfides provides evidence for the crystallization of primary PGM under $\mathrm{fS}_{2}$ as low as to prevent formation of Pt sulfides. Primary precipitation of sulfides at high temperature is reported exclusively from the Uktus chromitite where laurite with low Os content and kashinite with Ir-Ni-sulfide (Figure 7A) occur included in fresh chromite. The study of Kytlym and Uktus chromitites [23] allows identification of three groups of primary Pt-Fe alloys (Figure 8). The most abundant alloys consist of isoferroplatinum $\mathrm{Pt}_{3} \mathrm{Fe}$ and tetraferroplatinum $\mathrm{PtFe}$ containing less than 3 at $\% \mathrm{Ni}+\mathrm{Cu}$. These alloys, mainly $\mathrm{Pt}_{3} \mathrm{Fe}$, are preferentially accompanied by a sulfide-rich assemblage, erlichmanite, $\mathrm{Ir}-\mathrm{Rh}-\mathrm{Cu}-\mathrm{Ni}$ thiospinels, and pentlandite occurring as epitaxic overgrowth at the alloy's boundary (Figures 7B-F). This indicates that the alloys were a stable phase under relatively high $\mathrm{fS}_{2}$ capable of stabilizing the suite of PGM sulfides reported in the pictures. In contrast, isoferroplatinum and tetraferroplatinum both enriched in $\mathrm{Ni}$ and $\mathrm{Cu}$, would appear to have formed at relatively low $\mathrm{fS}_{2}$ as suggested by failure to crystallize $\mathrm{Ni}-\mathrm{Cu}$ Ir-thiospinels and erlichmanite (Figure 7G-I). 
Table 4. Electron microprobe analyses (wt \%) of PGM in ophiolitic chromitites of the Urals.

\begin{tabular}{|c|c|c|c|c|c|c|c|c|c|c|c|c|c|c|}
\hline Locality & PGM & Figure & Os & Ir & $\mathbf{R u}$ & Rh & $\mathbf{P t}$ & Pd & $\mathrm{Fe}$ & $\mathrm{Ni}$ & $\mathrm{Cu}$ & $\mathbf{S}$ & As & Tot \\
\hline Uktus & Laurite & & 8.12 & 5.46 & 47.50 & 2.16 & 0.00 & 0.00 & 0.74 & 0.04 & 0.00 & 35.60 & & 99.62 \\
\hline Uktus & Laurite & & 23.20 & 7.91 & 34.80 & 0.60 & 0.00 & 0.00 & 0.62 & 0.01 & 0.00 & 31.90 & & 99.04 \\
\hline Uktus & kashinite & $7 \mathrm{~A}$ & 1.54 & 52.40 & 0.30 & 18.40 & 0.28 & 0.00 & 1.40 & 0.37 & 0.18 & 22.90 & & 97.77 \\
\hline Uktus & $\mathrm{Ir}-\mathrm{Ni}-\mathrm{S}$ & $7 \mathrm{~A}$ & 0.32 & 34.50 & 0.01 & 10.10 & 0.43 & 0.00 & 6.43 & 14.50 & 3.84 & 25.20 & & 95.33 \\
\hline Uktus & $\mathrm{Pt}_{3} \mathrm{Fe}$ & 7C & 0.23 & 1.49 & 0 & 0.79 & 84.90 & 0 & 8.50 & 0.28 & 0.36 & 0.00 & 0.02 & 96.57 \\
\hline Uktus & cuprorhodsite & $7 \mathrm{E}$ & 0.21 & 32.20 & 0.00 & 26.30 & 0.92 & 0.00 & 0.48 & 0.98 & 9.36 & 26.90 & 0.04 & 97.39 \\
\hline Uktus & $\mathrm{Pt}_{3} \mathrm{Fe}$ & $7 \mathrm{E}$ & 0 & 0.96 & 0 & 0.36 & 88.70 & 0.33 & 8.90 & 0.28 & 0.21 & 0.00 & 0 & 99.74 \\
\hline Uktus & $\mathrm{Pt}_{3} \mathrm{Fe}$ & $7 \mathrm{~F}$ & 0.18 & 1.33 & 0.01 & 0.88 & 84.10 & 0.17 & 8.40 & 0.35 & 0.23 & 0.00 & 0.13 & 95.78 \\
\hline Uktus & Osmium & 7I & 96.90 & 1.29 & 0.18 & 0.13 & 2.00 & 0.00 & 0.02 & 0.04 & 0.00 & 0.00 & 0.01 & 100.57 \\
\hline Uktus & $\mathrm{Pt}_{3} \mathrm{Fe}$ & $7 \mathrm{I}$ & 0.13 & 0.80 & 0.05 & 1.19 & 84.56 & 0.02 & 10.27 & 0.28 & 0.39 & & & 97.68 \\
\hline Kytlym & $\mathrm{Pt}_{3} \mathrm{Fe}$ & $7 \mathrm{~B}$ & 2.5 & 2.04 & 0.09 & 1.35 & 84.76 & 0.19 & 8.56 & 0.23 & 0.19 & 0.00 & 0.04 & 99.95 \\
\hline Kytlym & erlichmanite & $7 \mathrm{~B}$ & 42.01 & 3.55 & 16.28 & 2.31 & 6.77 & 0.23 & 0 & 0.09 & 0.01 & 26.04 & 0 & 97.29 \\
\hline Kytlym & $\mathrm{Pt}_{3} \mathrm{Fe}$ & $7 \mathrm{D}$ & 0.18 & 0.24 & & 0.62 & 87.30 & 0.86 & 9.00 & 0.39 & 0.45 & & & 99.04 \\
\hline Kytlym & erlichmanite & 7D & 53.33 & 3.16 & 5.53 & 5.08 & 0.00 & 0.65 & 0.00 & 2.11 & 0.28 & 26.96 & 0.00 & 97.10 \\
\hline Kytlym & Rh-lr sulfide & 7D & 11.90 & 12.40 & 0.63 & 13.30 & 6.61 & 0.00 & 11.90 & 9.76 & 4.04 & 26.30 & 0.02 & 96.86 \\
\hline Kytlym & $\mathrm{PtFe}$ & $7 G$ & 0.11 & 0.87 & 0.04 & 1.29 & 83.10 & 0.33 & 12.00 & 2.98 & 1.09 & & & 101.81 \\
\hline Kytlym & Osmium & $7 \mathrm{H}$ & 87.00 & 6.24 & 0.40 & 0.44 & 2.98 & 0.07 & 0.29 & 0.19 & 0.00 & & 0.05 & 97.66 \\
\hline Kytlym & $\mathrm{PtFe}$ & $7 \mathrm{H}$ & 0.18 & 1.01 & 0.00 & 1.04 & 75.14 & 0.33 & 14.52 & 4.84 & 2.37 & 0.00 & 0.11 & 99.54 \\
\hline
\end{tabular}




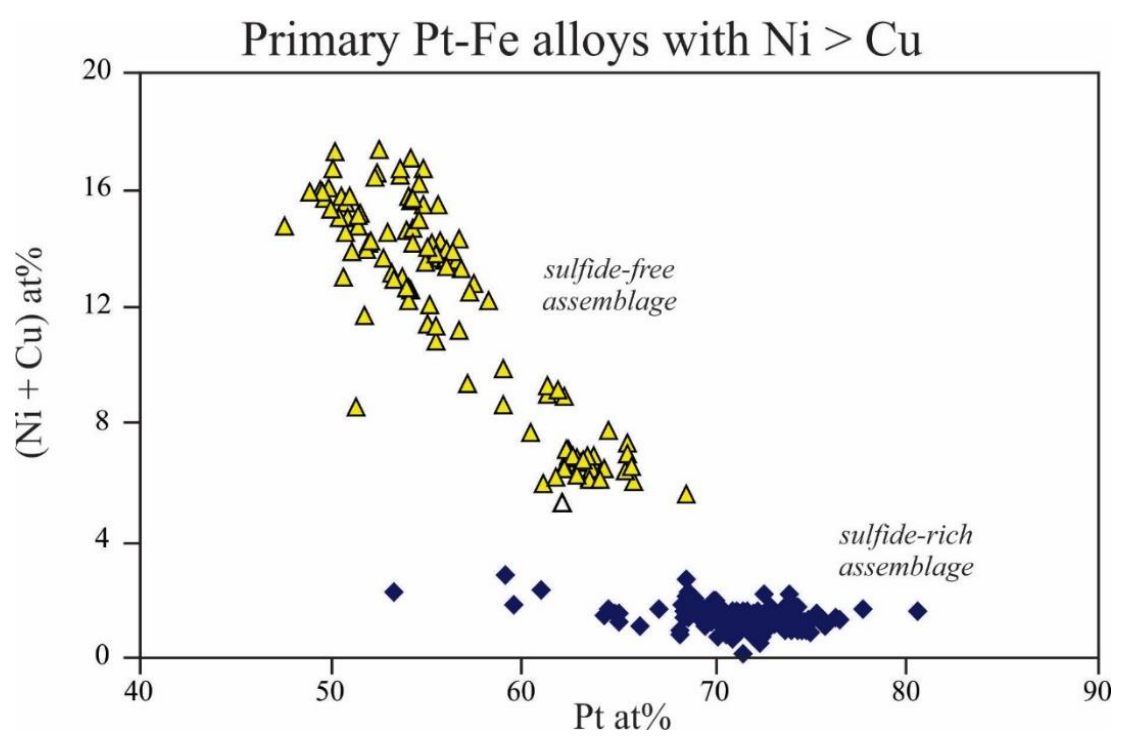

Figure 8. Variation of the $(\mathrm{Ni}+\mathrm{Cu})$ content in primary $\mathrm{Pt}-\mathrm{Fe}$ alloys occurring in sulfide-free or sulfide-rich PGM assemblages from the syngenetic chromitites of Kytlym and Uktus. Under low sulfur fugacity (sulfide free assemblage) $\mathrm{Ni}$ and $\mathrm{Cu}$ cannot form independent sulfides but are forced to enter the alloy structure substituting for platinum as supported by the $\mathrm{Pt}-(\mathrm{Ni}+\mathrm{Cu})$ negative correlation $(\mathrm{R}=-0.9)$.

According to the authors [23], the $\mathrm{fS}_{2}$ exerts strong influence on the composition and paragenetic assemblage of primary $\mathrm{Pt}-\mathrm{Fe}$ alloys crystallizing at high temperature. At low $\mathrm{fS}_{2}$ both $\mathrm{Ni}$ and $\mathrm{Cu}$ are forced to enter the alloy structure in substitution for $\mathrm{Pt}$, as indicated by the $\mathrm{Pt} /(\mathrm{Ni}+\mathrm{Cu})$ negative correlation in Figure 8. At relatively higher $\mathrm{fS}_{2} \mathrm{Ni}$ and $\mathrm{Cu}$ tend to form independent sulfides with $\mathrm{Ir}$ and Rh overgrowing the Pt-Fe alloys. An Os-alloy is usually present as exsolved lamellae in the Pt-Fe alloys. Its textural relations support the inferred variation of $\mathrm{fS}_{2}$ during crystallization of primary inclusions. The osmium lamellae are very small or absent in Pt-Fe alloys formed at high $\mathrm{fS}_{2}$, in which Os is mainly carried in primary erlichmanite. On the contrary, large osmium lamellae are almost ubiquitous in $\mathrm{Ni}-\mathrm{Cu}$ rich $\mathrm{Pt}-\mathrm{Fe}$ alloys occurring in the sulfide free PGM assemblage (Figure 7). The composition of primary laurite incusions of the Uktus chromitites remain confined to Os concentrations lower than about $10 \mathrm{at} \%$, therefore indicating crystallization at sulfur fugacities $\operatorname{logfS}_{2}$ close to -1.3 and a temperature of the order of $1300{ }^{\circ} \mathrm{C}$, for the near-end-member laurite [24]. The Figure 5 shows that these conditions are comparable with those obtained for initial PGM precipitation within upper mantle chromitites of the ophiolites [22,53]. The presence of erlichmanite in the PGM paragenesis indicates that sulfur fugacity reached the $\mathrm{Os}-\mathrm{OsS}_{2}$ reaction line at about $\operatorname{logfS} \mathrm{S}_{2}=1.0$ and $1100{ }^{\circ} \mathrm{C}$, but did not increase futher-above this limit.

\subsection{The Role of Oxygen Fugacity and Temperature}

Results of the olivine-spinel thermobarometer indicate that the crystallization-equilibration of syngenetic chromitite and accessory chromite in dunite follows a unique trend (Figure 9A) indicating that oxygen fugacity $\mathrm{fO}_{2}$ was increasing during fractionation of dunite to massive chromitite [24]. At the same time, the data support that massive chromitite equlibrated at higher temperature compared with the accessory chromite in dunite, possibly due to higher olivine/chromite mass ratio in the latter. In [24] it was shown that the oxidation ratio $\mathrm{Fe}^{3+} /\left(\mathrm{Fe}^{3+}+\mathrm{Fe}^{2+}\right)$ in the Uktus chromitites correlates positively with the increase of oxygen fugacity in the system and, significantly, it displays distinct correlation with variation of the assemblage of primary PGM inclusions in chromite (Figure 9B). The magnesiochromite with low oxidation ratio $\left[\mathrm{Fe}^{3+} /\left(\mathrm{Fe}^{3+}+\mathrm{Fe}^{2+}\right)=0.23-0.25\right]$ characterize the chromitites in the lowermost dunite body of the complex, where the PGM inclusions display high concentration of Ru-Os-Ir sulfides 
(laurite, kashinite, cuproiridsite) and the extreme paucity or absence of Pt-minerals. With proceeding differentiation, the oxidation ratio of the chromite increases up to $\mathrm{Fe}^{3+} /\left(\mathrm{Fe}^{3+}+\mathrm{Fe}^{2+}\right)=0.44$, and abundant $\mathrm{Pt}-\mathrm{Fe}$ alloys (isoferroplatinum, tetraferroplatinum) start to crystallize with the sulfide rich assemblage described above. The most differentiated chromitite characterizes for a Fe-rich composition and high oxidation ratio $\left[\mathrm{Fe}^{3+} /\left(\mathrm{Fe}^{3+}+\mathrm{Fe}^{2+}\right)=0.59\right]$ resembling "chromian titanomagnetite". The PGM are mainly composed of $\mathrm{Pt}$ and $\mathrm{Pd}$ as expected for the common trend of PGE magmatic fractionation, although the minerals mainly occupy the interstitial space among chromite grains and occur in typical secondary PGM assemblage characterized by abundance of As- Sb-, Te-phase [24]. The isoferroplatinum and sulfide PGM assemblage of Kytlym occurs in chromitite with an oxidation ratio of $\mathrm{Fe}^{3+} /\left(\mathrm{Fe}^{3+}+\right.$ $\left.\mathrm{Fe}^{2+}\right)=0.45$. In contrast, syngenetic chromites with a relatively high oxidation ratio $\left[\mathrm{Fe}^{3+} /\left(\mathrm{Fe}^{2+}+\mathrm{Fe}^{3+}\right)\right.$ $=0.52$ ] contain $\mathrm{Ni}-\mathrm{Cu}$ rich Pt-Fe alloys but no sulfide (Figure $9 \mathrm{~B}$ ), indicating that $\mathrm{fO}_{2}$ was increasing concomitant with a significant depression in $\mathrm{fS}_{2}$ [23].
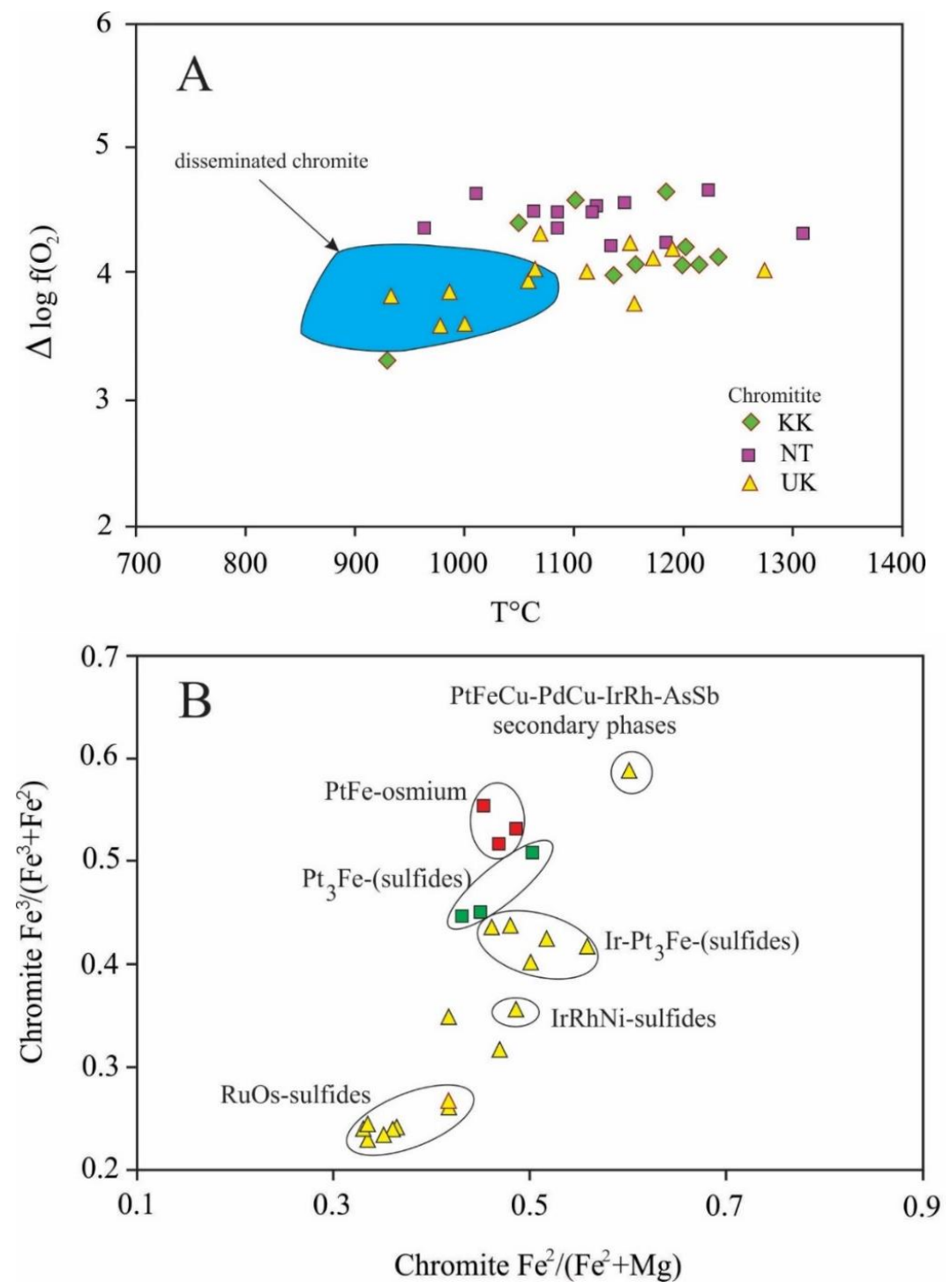

Figure 9. (A) Variation of oxygen fugacity as function of temperature in syngenetic chromitite and accessory chrome spinel disseminated in the host dunite. (B) The PGM assemblage in the syngenetic chromitites of Uktus (triangle) and Kytlym (square) evolves from enriched in Ru-Os and Ir sulfides into $\mathrm{Pt}-\mathrm{Fe}$ alloy dominated with increasing oxydation ratio of the chromite. 


\subsection{Thermodynamic Conditions for Precipitation of Primary Pt-Fe Alloys}

Considering the results of olivine-chromite thermobarometry in the Alaskan-type syngenetic chromitites of the Urals $[24,33,46,54]$ and the maximum stability temperature of $\mathrm{Pt}-\mathrm{Fe}$ alloys in a S-poor system, we may assume that the Pt-Fe alloys occurring as primary inclusions were trapped in the chromite as solid crystals, at temperatures in the range of $1050-1300{ }^{\circ} \mathrm{C}$, and oxygen fugacity from +2.1 to +4.9 deltalog $\left(\mathrm{O}_{2}\right)$ above the FMQ buffer. These emphasizes the anomaluos behavior of $\mathrm{Pt}$ that co-precipitates with the refractory Ir, and is not removed from the melt together with the companion $\mathrm{Rh}$ and $\mathrm{Pd}$ as a result of the segregation of a magmatic sulfide liquid [24,57]. The discrepancy with chromitites from other geological settings (i.e., the continental layered intrusions) is evident, and has received diverse explanations. Among others, one possible model assumes that the increase in $\mathrm{f}\left(\mathrm{O}_{2}\right)$ required for the crystallization of chromite might have been responsible for the sharp drop of $\mathrm{Pt}$ solubility in the silicate melt, causing precipitation of the $\mathrm{Pt}-\mathrm{Fe}$ alloys [58,59]. However, reversing this cause-effect order, [24] proposed that it was the strong tendency of $\mathrm{Pt}$ to combine with Fe to form $\mathrm{Pt}-\mathrm{Fe}$ alloys that caused the Pt-solubility falling down. According to this mechanism, the extensive stabilization of $\mathrm{Pt}-\mathrm{Fe}$ alloys at high temperature may actually reflect the anomalous increase of the $\mathrm{FeO}$ and $\mathrm{Fe}_{2} \mathrm{O}_{3}$ activity in the magma parent to Alaskan-type chromitites, that is a major consequence expected from the $\mathrm{SiO}_{2}$-undersaturation condition of these melts. The effect on chromite composition would be the incorporation of larger amounts of magnetite component $\left(\mathrm{FeOFe}_{2} \mathrm{O}_{3}\right)$ in the chromite structure, thus simulating an increase of $\mathrm{f}\left(\mathrm{O}_{2}\right)$ in the system [60]. For this reason, primary precipitation of $\mathrm{Pt}-\mathrm{Fe}$ occurs preferentially in mafic magmas having olivine (not orthopyroxene) and chromite with relatively high oxidation ratio, $\mathrm{Fe}^{3+}\left(\mathrm{Fe}^{2+}+\mathrm{Fe}^{3+}\right)$, on the liquidus: the Alaskan-type magmas.

\section{Conclusions}

The review based on examination of more than 2500 analyses of PGM associated with ophiolitic and Alaskan-type chromitites of the Urals reveals that mineralogy of PGM crystallizing at high temperature is controlled by: (1) the nature of the parent melt and relative concentrations of PGE; (2) the presence of melt-soluble clusters of PGE in the parent melt; and (3) by the chemical-physical conditions such as temperature, sulfur- and oxygen-fucagity, prevailing during their precipitation.

The mineralogy of PGM inclusions in ophiolitic and Alaskan-type chromitites of the Urals is consistent with reported whole-rock PGE concentrations. In particular, the ophiolitic chromitites contain abundant Os-Ir-Ru minerals and rare Rh-Pt-Pd phases, whereas the most abundant PGM in the Alaskan-type chromitites are Pt-Fe alloys accompanied by minor Ir-Os-Rh phases.

The most important factors controlling the precipitation of PGM in ophiolitic chromitites are temperature and sulfur fugacity. The mineralogical assemblage shows that the chromitites formed in a narrow range of temperature $\left(1310-1090{ }^{\circ} \mathrm{C}\right)$ are characterized by the presence of PGM, such as laurite and alloys in the Os-Ir-Ru system, that require relatively low sulfur fucagity to precipitate. The chromitites that have suffered compositional re-equilibration in a wide thermal range (e.g., $1400-700{ }^{\circ} \mathrm{C}$ ) contain a great number of PGM, including erlichmanite and Ir-Ni-sulfides. This observation suggests that the post-magmatic equilibration under slow cooling-rate was responsible for the increasing of the sulfur fugacity and the formation of a volatile rich fluid, thus promoting precipitation of a variegate suite of PGM comprising alloys, sulfides, sulfarsenides, and arsenides. In this post-magmatic stage, all the PGE that were present in solid chromite as dispersed atomic clusters could easily be converted into discrete PGM inclusions splitting off the chromite structure.

The predominance of Pt-Fe alloys over sulfides in the Alaskan-type chromitites indicates that the crystallization of magmatic PGM occurred under fS2 as low as to prevent formation of Pt sulfides but was high enough to crystallize erlichmanite and Ir-Ru-Ni-Cu sulfides. The key factor for the precipitation of abundant $\mathrm{Pt}-\mathrm{Fe}$ alloys in the Alaskan-type chromitites is the $\mathrm{SiO}_{2}$-undersaturation condition of the parent melt and the oxygen fugacity that was increasing during fractionation of dunite 
to massive chromitite. The estimated temperatures suggest that the range of crystallization of PGM in the primary magmatic stage was comprised between 1050 and $1300{ }^{\circ} \mathrm{C}$.

In summary, the whole scenario provides further support to the conclusion that the majority of primary PGM inclusions in chromite formed in situ as part of the chromite precipitation event, and eventually was modified during post-magmatic, slow cooling conditions. Only a few high refractory PGM might have formed during partial melting in the deep mantle source, being transported as suspended solid particles to the site of chromite deposition

Author Contributions: F.Z. and G.G. wrote and organized the paper. E.P. collected some of the studied samples and provided the geological and field information. O.T. revised the English. All the authors contributed to the interpretation of the data and to organize the manuscript.

Funding: E.P is grateful to the grant by the Russian Foundation of Basic Research (RFBR grant No. 16-05-00508-a).

Acknowledgments: The Editorial staff of minerals is thanked for the efficient assistance. The comments of two anonymous referees improved the manuscript. The University Centrum for Applied Geosciences (UCAG) is thanked for the access to the E. F. Stumpfl electron microprobe laboratory. This manuscript is dedicated to German Fershtater, Ural Branch of the Russian Academy of Science.

Conflicts of Interest: The authors declare no conflict of interest.

\section{References}

1. Barnes, S.J.; Naldrett, A.J.; Gorton, M.P. The origin of the fractionation of Platinum-group elements in terrestrial magmas. Chem. Geol. 1985, 53, 303-323. [CrossRef]

2. Cabri, L.J.; Naldrett, A.J. The nature, distribution, and concentrations of platinum-group elements in various geological environments. In Proceedings of the 27th International Geological Congress, Moscow, Russia, 4-14 August 1984; pp. 10-27.

3. Crocket, J.H. Geochemistry of the Platinum-Group Elements. In Platinum-Group Elements: Mineralogy, Geology, Recovery; Cabri, L.J., Ed.; Geology Division of CIM: Ottawa, ON, Canada, 1981; pp. 47-64.

4. Legendre, O.; Augé, T. Mineralogy of platinum-group mineral inclusions in chromitites from different ophiolite complexes. In Metallogeny of Basic and Ultrabasic Rocks; Gallagher, M.J., Ixer, R.A., Neary, C.R., Prichard, H.M., Eds.; Springer: Amsterdam, The Netherlands, 1986; pp. 361-372.

5. Page, N.J.; Cassard, D.; Haffty, J. Palladium, platinum, rhodium, ruthenium and iridium in chromitites from the Massif du Sud and Tiebaghi massif, New Caledonia. Econ. Geol. 1982, 77, 1571-1577. [CrossRef]

6. Talkington, R.W.; Watkinson, D.M.; Whittaker, P.J.; Jones, P.C. Platinum-group minerals and other solid inclusions in chromite of ophiolitic complexes: Occurrence and petrological significance. Tschermaks Mineralogische Petrogr. Mitt. 1984, 32, 285-301. [CrossRef]

7. Rudashevskiy, N.S. Origin of various types of platinoid mineralization in ultramafic rocks. Int. Geol. Rev. 1987, 29, 465-480. [CrossRef]

8. Garuti, G.; Zaccarini, F. In situ alteration of platinum-group minerals at low temperature: evidence from serpentinized and weathered chromitite of the Vourinos Complex, Greece. Can. Mineral. 1997, 35, 611-626.

9. Capobianco, C.J.; Drake, M.J. Partitioning of ruthenium, rhodium, and palladium between spinel and silicate melt and implications for platinum-group element fractionation trends. Geochim. Cosmochim. Acta 1990, 54, 869-874. [CrossRef]

10. Garuti, G.; Gazzotti, M.; Torres-Ruiz, J. Iridium, rhodium, and platinum sulfides in c chromitites from the ultramafic massifs of Finero, Italy, and Ojen, Spain. Can. Mineral. 1995, 33, 509-520.

11. Constantinides, C.C.; Kingston, G.A.; Fisher, P.C. The occurrence of platinum group minerals in the chromitites of the Kokkinorotsos chrome mine, Cyprus. In Ophiolites, Proceedings of the International Ophiolite Symposium, Cyprus 1979; Panayiotou, A., Ed.; Geological Survey Department: Nicosia Cyprus, 1980; pp. 93-101.

12. Stockman, H.W.; Hlava, P.F. Platinum-group minerals in Alpine chromitites from southwestern Oregon. Econ. Geol. 1984, 79, 491-508. [CrossRef] 
13. Augé, T.; Johan, Z. Comparative study of chromite deposits from Troodos, Vourionos, North Oman and New Caledonia ophiolites. In Mineral Deposits within the European Community; Spec. publication n. 6, of the Society for Geology Applied to Mineral Deposits; Boissonnas, J., Omenetto, P., Eds.; Springer: Berlin/Heidelberg, Germany, 1988; pp. 267-288.

14. Tredoux, M.; Lyndsay, N.M.; Devis, G.; MacDonald, I. The fractionation of platinum-group elements in magmatic systems, with the suggestion of a novel causal mechanism. S. Afr. J. Geol. 1995, 98, 157-167.

15. Garuti, G. Chromite-platinum-group element magmatic deposits. In Geology, Encyclopedia of Life Support Systems (EOLSS) UNESCO; De Vivo, B., Stäwe, K., Grasemann, B., Eds.; Eolss Publisher: Oxford, UK, 2004.

16. Razin, L.V. Geologic and genetic features of forsterite dunites and their platinum-group mineralization. Econ. Geol. 1976, 71, 1371-1376. [CrossRef]

17. Makeyev, A.B.; Kononkova, N.N.; Kraplya, E.A.; Chernukha, F.P.; Bryanchaninova, N.I. Platinum Group Minerals in alluvium of the Northern Urals and Timan: The key to primary sources of platinum. Trans. Acad. Sci. Earth Sci. Sect. 1997, 353, 181-184.

18. Anikina, Ye.V.; Pushkarev, E.V.; Garuti, G.; Zaccarini, F.; Cabella, R. The Evolution of Chrome Spinel Composition and PGE Minerals in the Dunite of the Uktus Massif (Middle Urals); Institute of Geology and Geochemistry Ekaterimburg: Ekaterimburg, Russia, 1996; p. 9. (In Russian)

19. Augé, T.; Genna, A.; Legendre, O.; Ivanov, K.S.; Volchenko, Y.A. Primary platinum mineralization in the Nizhny Tagil and Kachkanar ultramafic complexes, Urals, Russia: A genetic model for PGE concentration in chromite-rich zones. Econ. Geol. 2005, 100, 707-732. [CrossRef]

20. Distler, V.; Kryachko, V.V.; Yudovskaya, M.A. Ore petrology of chromite-PGE mineralization in the Kempirsai ophiolite complex. Mineral. Petrol. 2008, 92, 31-58. [CrossRef]

21. Garuti, G.; Zaccarini, F.; Cabella, R.; Fershtater, G.B. Occurrence of unknown Ru-Os-Ir-Fe oxide in the chromitites of the Nurali ultramafic complex, southern Urals, Russia. Can. Mineral. 1997, 35, 1431-1440.

22. Garuti, G.; Zaccarini, F.; Moloshag, V.; Alimov, V. Platinum-group minerals as indicators of sulfur fugacity in ophiolitic upper mantle: An example from chromitites of the Ray-Iz ultramafic complex, Polar Urals, Russia. Can. Mineral. 1999, 37, 1099-1116.

23. Garuti, G.; Pushkarev, E.; Zaccarini, F. Composition and paragenesis of Pt-alloys from chromitites of the Ural-Alaskan-Type Kitlim and Uktus complexes, northern and central Urals, Russia. Can. Mineral. 2002, 40, 1127-1146. [CrossRef]

24. Garuti, G.; Pushkarev, E.; Zaccarini, F.; Cabella, R.; Anikina, E. Chromite composition and platinum-group mineral assemblage in the Uktus Uralian-Alaskan-type complex (Central Urals, Russia). Mineral. Deposita 2003, 38, 312-326. [CrossRef]

25. Grieco, G.; Diella, V.; Chaplygina, N.L.; Savelieva, G.N. Platinum group elements zoning and mineralogy of chromitites from the cumulate sequence of the Nurali massif (Southern Urals, Russia). Ore Geol. Rev. 2007, 30, 257-276. [CrossRef]

26. Ivanov, O.K. Zoned Ultramafic Complexes of the Urals (Mineralogy, Petrology, Genesis); Uralian University Publishing House: Ekaterinburg, Russia, 1997; p. 488. (In Russian)

27. Melcher, F.; Stumpfl, E.F.; Simon, G. Platinum-group minerals and associated inclusions in chrome spinel of the Kempirsai ultramafic massif, Southern Urals, Kazakhstan. In Mineral Deposits; Pašava, K.Z., Ed.; Balkema: Rotterdam, The Netherlands, 1995; pp. 153-156.

28. Melcher, F.; Grum, W.; Simon, G.; Thalhammer, T.V.; Stumpfl, E.F. Petrogenesis of the ophiolitic giant chromite deposits of Kempirsai, Kazakhstan: a study of solid and fluid inclusions in chromite. J. Petrol. 1997, 38, 1419-1458. [CrossRef]

29. Melcher, F. Base metal-platinum group element sulfides from the Urals and the Eastern Alps: Characterization and significance for mineral systematics. Mineral. Petrol. 2000, 68, 177-211. [CrossRef]

30. Moloshag, V.P.; Smirnov, S.V. Platinum mineralization of the Nurali mafic-ultramafic massif (Southern Urals). Notes Rus. Mineral. Soc. Part. 1996, 125, 48-54. (In Russian)

31. Pašava, J.; Knésl, I.; Vymazalová, A.; Vavřín, I.; Ivanovna Gurskaya, L.; Ruslanovich Kolantsev, L. Geochemistry and mineralogy of platinum-group elements (PGE) in chromites from Centralnoye I, Polar Urals, Russia. Geosc. Front. 2011, 2, 81-85. [CrossRef]

32. Pushkarev, E.V. Petrology of the Uktus Dunite-Clinopyroxenite-Gabbro Massif (the Middle Urals); Russian Academy of Sciences, Ural Branch, Institute of Geology and Geochemistry: Ekaterinburg, Russia, 2000; pp. 1-296. (In Russian) 
33. Pushkarev, E.V.; Anikina, E.V. Low temperature origin of the Ural-Alaskan type platinum deposits: Mineralogical and geochemical evidence. In Proceedings of the 9th International Platinum Symposium, Billings, Montana, MT, USA, 21-25 July 2002; pp. 387-390.

34. Pushkarev, E.V.; Anikina, E.V.; Garuti, G.; Zaccarini, F. Chromium-Platinum deposits of Nizhny-Tagil type in the Urals: Structural-substantial characteristic and a problem of genesis. Litosfera. 2007, 3, 28-65. (In Russian)

35. Sedler, I.K.; Wipfler, E.L.; Anikina, E.V. Platinum group minerals and associated chrome-spinels of the Alaskan-type Nizhny Tagil massif, Middle Urals. In Mineral Deposits: Processes to Processing; Stanley, C.J., Ed.; Taylor \& Francis: Rotterdam, The Netherlands, 1999; pp. 787-790.

36. Smirnov, S.V.; Moloshag, V.P. Two types of Platinum deposits of the Nuraly ultramafic pluton (South Urals). In Proceedings of the VII International Platinum Symp, Moskow, Russia, 1-4 August 1994.

37. Thalhammer, T.V. The Kempirsai Ophiolite Complex, South Urals. Petrology, Geochemistry, Platinum-Group Minerals, Chromite Deposits. Ph.D. Thesis, University of Leoben, Leoben, Austria, 1996.

38. Zaccarini, F. Comparative Study of Platinum-Group Minerals in Podiform Chromitites from Mesozoic, Paleozoic, and Precambrian Ophiolite Complexes: Examples from the Mediterranean Area, the Ural Chain, and the Egyptian Eastern Desert. Ph.D. Thesis, University of Bologna, Bologna, Italy, 1999; p. 135. (In Italian)

39. Zaccarini, F.; Pushkarev, E.; Fershtater, G.B.; Garuti, G. Composition and mineralogy of PGE-rich chromitites in the Nurali Lherzolite-gabbro complex, southern Urals, Russia. Can. Mineral. 2004, 42, 545-562. [CrossRef]

40. Zaccarini, F.; Pushkarev, E.; Garuti, G. Platinum-group element mineralogy and geochemistry of chromitite of the Kluchevskoy ophiolite complex, central Urals (Russia). Ore Geol. Rev. 2008, 33, 20-30. [CrossRef]

41. Zaccarini, F.; Garuti, G.; Pushkarev, E. V. Unusually PGE-rich chromitite in the Butyrin vein of the Kytlym Uralian-Alaskan complex, Northern Urals, Russia. Can. Mineral. 2011, 49, 52-72. [CrossRef]

42. Zaccarini, F.; Garuti, G.; Bakker, R.J.; Pushkarev, E.V. Electron microprobe and Raman Spectroscopy investigation of an oxygen-bearing $\mathrm{Pt}-\mathrm{Fe}-\mathrm{Pd}-\mathrm{Ni}-\mathrm{Cu}$ compound from Nurali chromitite (Southern Urals, Russia). Microsc. Microanal. 2015, 21, 1070-1079. [CrossRef] [PubMed]

43. Zaccarini, F.; Bindi, L.; Pushkarev, E.V.; Garuti, G.; Bakker, R.J. Multi-analytical characterization of minerals of the bowieite-kashinite series from Svetly Bor complex, Urals (Russia) and comparison with worldwide occurrences. Can. Mineral. 2015, 54, 461-473. [CrossRef]

44. Zaccarini, F.; Pushkarev, E.V.; Garuti, G.; Kazakov, I. Platinum-Group Minerals and other accessory phases in chromite deposits of the Alapaevsk ophiolite, Central Urals, Russia. Minerals 2016, 6, 108. [CrossRef]

45. Zoloev, K.K.; Volchenko, Yu.A.; Koroteev, V.A.; Malakhov, I.A.; Mardirosyan, A.N.; Khripov, V.N. Platinum Ores in Different Complexes of the Urals; Ural State University Press: Ekaterinburg, Russia, 2001; p. 199. (In Russian)

46. Garuti, G.; Pushkarev, E.; Thalhammer, O.A.R.; Zaccarini, F. Chromitites of the Urals (Part 1): Overview of chromite mineral chemistry and geo-tectonic setting. Ofioliti 2012, 37, 27-53.

47. Betekhtin, A.G. Mikroskopische Untersuchungen an Platinerzen aus dem Ural. N. Jb. Miner. Abh. 1961, 97, $1-34$.

48. Garuti, G.; Pushkarev, E.V.; Zaccarini, F. Diversity of chromite-PGE mineralization in ultramafic complexes of the Urals. In Proceedings of the Platinum-Group Elements-From Genesis to Beneficiation and Environmental Impact: 10th International Platinum Symposium, Oulu, Finland, 8-11 August 2005; Geological Survey of Finland: Esbo, Finland, 2005.

49. Kojonen, K.; Zaccarini, F.; Garuti, G. Platinum-Group-Elements and gold geochemistry and mineralogy in the Ray-Iz ophiolitic chromitites, Polar Urals. In Mineral Exploration and Sustainable Development; Eliopoulos, D.G., Ed.; Millpress: Rotterdam, The Netherlands, 2003; pp. 599-602.

50. Naldrett, A.J.; Duke, J.M. Platinum metals in magmatic sulfide ores. Science 1980, 208, 1417-1424. [CrossRef] [PubMed]

51. Wood, S.A. Thermodynamic calculation of the volatility of the platinum group elements (PGE): The PGE content of fluids at magmatic temperatures. Geochim. Cosmochim. Acta. 1987, 51, 3041-3050. [CrossRef]

52. Ferrario, A.; Garuti, G. Platinum-group mineral inclusions in chromitites of the Finero mafic-ultramafic complex (Ivrea-Zone, Italy). Mineral. Petrol. 1990, 41, 125-143. [CrossRef]

53. Garuti, G.; Zaccarini, F.; Economou-Eliopoulos, M. Paragenesis and composition of laurite from chromitites of Othrys (Greece): Implication for Os-Ru fractionation in ophiolitic upper mantle of the Balkan Peninsula. Mineral. Deposita. 1999, 34, 312-319. [CrossRef] 
54. Chashchukhin, I.S.; Votyakov, S.L.; Uimin, S.G. Oxygen thermometry and barometry in chromite-bearing ultramafic rocks: An exmple of ultramafic massis on the Urals. II. Oxidation state of ultramafics and the composition of mineralizing fluids. Geochem. Int. 1998, 36, 783-791.

55. Ballahaus, C.; Berry, R.F.; Green, D.H. High-pressure experimental calibration of the olivineorthopyroxene.spinel geobarometer: Implications for the oxidation state of the upper mantle. Contr. Mineral. Petrol. 1991, 107, 27-40. [CrossRef]

56. Westland, A.D. Inorganic chemistry of the platinum group elements. In Platinum Group Elements: Mineralogy, Geology, Recovery; Cabri, L.J., Ed.; Geology Division of CIM: Ottawa, ON, Canada, 1981; pp. 5-18.

57. Garuti, G.; Fershtater, G.B.; Bea, F.; Montero, P.; Pushkarev, E.; Zaccarini, F. Platinum-group elements as petrological indicators in mafic-ultramafic complexes of the central and southern Urals. Tectonophysics 1997, 276, 181-194. [CrossRef]

58. Amossé, J.; Allibert, M.; Fisher, W.; Piboule, M. Experimental study of the solubility of platinum and iridium in basic silicate melts-implications for the differentiation of platinum group elements during magmatic processes. Chem. Geol. 1990, 81, 45-53. [CrossRef]

59. Nixon, G.T.; Cabri, L.J.; Laflamme, J.H.G. Platinum group elements mineralization in lode and placer deposits associated with the Tulameen Alaskan type complex, British Columbia. Can. Mineral. 1990, 28, 503-535.

60. Irvine, T.N. Chromian spinel as a petrogenetic indicator. Part 2. Petrologic applications. Can. J. Earth Sci. 1967, 4, 71-103. [CrossRef]

(C) 2018 by the authors. Licensee MDPI, Basel, Switzerland. This article is an open access article distributed under the terms and conditions of the Creative Commons Attribution (CC BY) license (http://creativecommons.org/licenses/by/4.0/). 